\title{
THE HISTORY OF TRANSPORTATIONS OF STOATS (MUSTELA ERMINEA) AND WEASELS (M. NIVALIS) TO NEW ZEALAND, 1883-92
}

\author{
CAROLYN M. KING \\ Environmental Research Institute, \\ School of Science, University of Waikato, \\ Hamilton, New Zealand
}

\section{Abstract}

This article presents an intensive original analysis of the history of the first deliberate transportations of non-domesticated European predators into southern New Zealand during the second half of the nineteenth century. It was part of one of the world's first large-scale attempts to use alien carnivores as agents of biological control against a major vertebrate pest. In response to serious pasture damage in Southland and Otago by European rabbits, and the consequent decline in the value of wool exports, tens of thousands of the rabbits' 'natural enemies', semi-tame ferrets, and pet cats collected from cities, were liberated on the worst-affected pastoral land, followed by wild-captured stoats and weasels. Against strong and repeated protests, at least 7,838 stoats and weasels were imported from Britain in at least 25 shipments between 1883 and 1892 . The total cost over the decade was probably at least NZ\$1-2 million in today's money, with no effect on the numbers of rabbits. The historic details of the mustelid introductions, never previously assembled, cast an unconventional light on an old story, concerning how powerful economic interests and dominant cultural assumptions determine official policy, with implications for thinking about contemporary ecological globalisation.

Keywords: biological invasions, New Zealand, rabbits, animal translocations, stoats, weasels, British imperialism, settler colonialism

\section{Introduction}

The term 'Anthropocene' summarises a cascade of dramatic social, cultural and economic changes around the globe over the last few hundred years. Colonial governments established via imperial expansion from western Europe assumed they had the power and authority to reshape nature to their own needs. The drastic 
transformation of the New Zealand landscape during the nineteenth century was part of the consequences of this wider movement, ${ }^{1}$ but pioneer expectations were often confounded. Rural settlers had to deal with the capacity of their new environment to 'throw up surprise after surprise'. ${ }^{2}$ As the historian Thomas Dunlap put it so well, 'The colonists spoke of conquest and command, but they learned to obey. ${ }^{3}$

As in England, but much more rapidly, ${ }^{4}$ native ecosystems were disrupted and replaced with 'improved' vegetation and imported animals. The contributions of the humanities toward understanding how this process unfolded in New Zealand are generally concerned with how Victorian assumptions of humanity's right to exert control over nature was challenged by contact with reality. ${ }^{5}$ Whilst the often unexpected doleful consequences are well recognised in the historical literature, few analyses of it have examined in any detail the organisation and catastrophic biological consequences of the deliberate introductions of mustelids to New Zealand to control rabbits.

The key questions in this context are: why did New Zealand's colonial government pursue this policy even against well-informed objections?; what can be learned from nineteenth-century experience of well-intentioned but naïve attempts to manipulate natural biological processes?; and are we coming to terms with the consequences? ${ }^{6}$

The historian Paul Star summarised the double significance of environmental history as a tool that helps not only those who try to understand the past, but also those responsible for managing the future. ${ }^{7}$ Nowhere does that idea apply more cogently than to the current aspiration to make New Zealand predator-free by $2050 .^{8}$ Two of the introduced species specifically targeted by this plan, the Australian brush-tail possum (Trichosurus vulpecula) and the stoat (Mustela erminea), were brought in

1 Alfred W. Crosby, Ecological Imperialism: The Biological Expansion of Europe, 900-1900 (Cambridge: Cambridge University Press, 1986); Thomas R. Dunlap, Nature and the English diaspora: Environment and history in the United States, Canada, Australia and New Zealand (Cambridge: Cambridge University Press, 1999); Robert Peden, Making Sheep Country: Mt Peel station and the transformation of the tussock lands (Auckland: Auckland University Press, 2011); Peter Holland, Home in the howling wilderness (Auckland: Auckland University Press, 2013); E. Pawson and A. A. Christensen, 'Landscapes of the Anthropocene: From dominion to dependence?', in Rethinking invasion ecologies from the environmental humanities, ed. J. Frawley and I. McCalman (London: Routledge, 2014), 64-83.

2 Holland, Home in the howling wilderness, 139.

3 Dunlap, Nature and the English diaspora, 73.

4 E. Pawson and T. Brooking, eds., Environmental histories of New Zealand (Melbourne: Oxford University Press, 2002).

5 H. Ritvo, 'Going Forth and Multiplying: Animal Acclimatization and Invasion', Environmental History 17 (2012): 404-14.

6 Paraphrased from Pawson and Christensen, 'Landscapes of the Anthropocene: From dominion to dependence?', 64-5.

$7 \quad$ P. Star, “Nature's Trump Card”: Confronting the rabbit problem in southern New Zealand, 1867-1897', ENNZ: Environment and Nature in New Zealand 1 (2006): 3-9.

8 B. Owens, 'The Big Cull: Can New Zealand pull off an audacious plan to get rid of invasive predators by 2050?', Nature 541 (2017): 148-50; J. C. Russell et al., 'Predator-Free New Zealand: Conservation Country', BioScience 65 (2015): 520-5, doi.org/10.1093/biosci/biv012. 
deliberately, repeatedly, and with great care, yet have created the very opposite of the economic benefits they were confidently expected to bring. So also was the European rabbit (Oryctolagus cuniculus), which in its time became the most devastating vertebrate pest in New Zealand's short history of agriculture, although in most places it is less so now than it was. The time is right for a closer look at how these surprising contradictions evolved.

\section{Setting the scene}

The environmental effects of European activities on the New Zealand native biota were recognised but often dismissed ${ }^{9}$ on the grounds that the endemic trees, birds, lizards and insects were already doomed to extinction. Charles Darwin himself saw, as early as 1835, that 'The endemic productions of New Zealand, for instance, are perfect one compared with another; but they are now rapidly yielding before the advancing legions of plants and animals introduced from Europe ${ }^{10}$ And not only from there. As acclimatisation progressed, many species came from Asia, especially India ${ }^{11}$ and China. ${ }^{12}$

Hardly surprising, then, that among the busy work of converting what the early settlers thought of as an empty landscape into productive farms, some also seized the opportunity to establish new and liberal opportunities for sport hunting and fishing. They not only worked hard to take advantage of the last large land area in the world still not colonised by Europeans in the early nineteenth century; ${ }^{13}$ they also populated the forests, grasslands and alpine heights with game mammals and birds (deer, chamois, Himalayan tahr, wallabies, hares, wild rabbits, pheasants, quail and partridges) and the rivers with fish (trout and salmon), so that the colonists could enjoy free access to the field sports that were restricted to wealthy landowners back Home. ${ }^{14}$ New Zealand was not the only recipient of wholesale acclimatisation fever, but it remains one of the more extreme examples. ${ }^{15}$

One of the most enthusiastic proponents of the acclimatisation of game species during the 1860s was Francis Dyer Rich, owner of Bushey Park near Palmerston, Otago (Figure 1). Rich was a keen supporter of acclimatisation, except of wild

\footnotetext{
9 Holland, Home in the howling wilderness, Chap. 4.

10 Charles Darwin, The Origin of Species (London: Folio Society, 2006) [reprint of 1st edition of 1859], 160.

11 James Beattie, 'Plants, Animals and Environmental Transformation: Indian-New Zealand Biological and Landscape Connections, 1830s-1890s', in The East India Company and the Natural World, ed. V. Damodaran,

A. Winterbottom and A. Lester (Basingstoke: Palgrave Macmillan, 2015), 219-48.

12 James Beattie, 'Acclimatisation and the "Europeanisation" of New Zealand, 1830s-1920s?', Environment and Nature in New Zealand 3 (2008): 1-12.

13 Dunlap, Nature and the English diaspora.

14 R. M. McDowall, Gamekeepers for the nation: The story of New Zealand's Acclimatisation Societies 1861-1990 (Christchurch: Canterbury University Press, 1994), 36.

15 Dunlap, Nature and the English diaspora; McDowall, Gamekeepers for the nation, 36.
} 
rabbits; rather, Rich imported deer, pheasants and hares in order to make his estate into a paradise for sportsmen, mainly fellow members of the Dunedin Club and of the local business hierarchy. ${ }^{16}$

In early 1880 two English gentlemen, Samuel Grant of Healing, and John S. Foster of Ludborough (Figure 1, inset), made a study tour of the farming districts of both main islands, on behalf of Lincolnshire tenant farmers considering emigration as an escape from increasingly difficult conditions at home. ${ }^{17}$ From their descriptions, one of the settlers who hosted them during their tour of the South Island, on an unnamed estate near Palmerston, was probably Rich.

The English visitors did not mention rabbits at all until they got to Southland, where they admitted that rabbits were becoming a serious nuisance. Nevertheless, they concluded that the prospects of New Zealand as a profitable site for emigration were very favourable: 'The run-holders have, in times past, made very large sums of money, and no doubt will continue to do so ...' ${ }^{18}$

Grant and Foster underestimated the damage already being caused by wild European rabbits $^{19}$ and causing serious alarm to runholders near their early liberation sites in Southland, ${ }^{20}$ Marlborough and Hawke's Bay (Figure 1). By the early 1880s, the devastation wrought by wild rabbits across Southland and Otago was forcing many formerly wealthy runholders into bankruptcy. ${ }^{21}$ After such a promising start, the speed and consequences of the rabbit invasion took everyone by surprise. ${ }^{22}$

\section{The idea of 'natural enemies'}

Modern readers accustomed to contemporary ecological principles tend not to appreciate why the European migrants were so astonished by this turn of events. In Europe at the time, human conceptions of the relationships between people

16 F. R. J. Sinclair, 'High Street Quaking: A history of Dunedin's "Inner Circle”' (PhD diss., University of Otago, 1996).

17 Samuel Grant and John S. Foster, New Zealand: A Report on its Agricultural Conditions and Prospects (London: G. Street, 1880).

18 Grant and Foster, New Zealand, 72, 76.

19 Grant and Foster's report was sponsored by the colonial government, with whom they negotiated a 'special settlement' for purchase of land provided they brought in a certain number of Lincolnshire farmers as permanent settlers. See Minister for Immigration, 'Messrs Grant and Foster's Special settlement at Te Aroha', Appendix to the Journals of the House of Representatives (AJHR) D-3 (Wellington: Government Printer, 1881). One cannot help wondering if one or other of the parties had some vested interest in underplaying the threat from the rabbit invasion. The deal fell through, and Grant was bankrupted in 1884. See 'The bankruptcy of a Lincolnshire farmer and land speculator', Thames Advertiser, 6 May 1884.

20 J. L. C. Richardson and W. H. Pearson, 'The Rabbit Nuisance in Southland', AJHR H-10 (1876).

21 Sinclair, 'High Street Quaking'.

22 J. A. Gibb and J. M. Williams, 'The rabbit in New Zealand', in The European Rabbit: The History and Biology of a Successful Colonizer, ed. H. V. Thompson and C. M. King (Oxford: Oxford University Press, 1994), 158-204. 
and nature were very different from now. From the time of the ancient Greeks, the universal assumption was that life on Earth has both balance and purpose. ${ }^{23}$ 'Balance' was variously defined as a stable state of nature, steadily maintained by the interactions between natural communities and their environment. This reassuring stability was seen as the result of the long-term coexistence of native species all keeping each other in check. In this view, disturbances to this mutual harmony, such as a short-term outbreak of caterpillars, would be soon corrected by increased attention from their natural enemies, caterpillar-eating birds.

In Europe, rabbits and their predators (stoats, weasels, polecats and foxes, crows and raptors) have co-evolved a set of mutually adaptive population dynamics and flexible behaviour that allow long-term coexistence at landscape scale. So the obvious answer to the question of why rabbits suddenly became so much more abundant in New Zealand than in Europe was that rabbits in New Zealand had been imported without their natural enemies. ${ }^{24}$ Natural enemies kill rabbits; too many rabbits meant not enough natural enemies; this seemed to be a problem with a simple and obvious solution. Rabbits free of any restraints had disturbed the balance of nature, so an organised, large-scale importation and release of stoats would soon restore it. ${ }^{25}$ The colonists reasoned that, since killing individuals reduced their numbers, killing enough of them would get rid of the problem, ${ }^{26}$ much as English gamekeepers had long-established methods of managing threats to managed game birds on shooting estates. ${ }^{27}$ No one at the time understood why the diversity of pastoral environments in New Zealand made the problem much more complicated than that. ${ }^{28}$

The assumption that natural enemies can and do control the numbers of their prey was then universally believed, and can be true, provided the two have roughly matching reproductive rates. The famous case of how imported natural enemies saved the citrus orchards of California from pest insects was being celebrated at about the same time (1888) as the Otago runholders were agitating to import more mustelids into New Zealand. ${ }^{29}$ The problem is, as John Kricher points out, since our actions are largely determined by what we believe about the way nature works, there will be serious consequences if what we believe is wrong. ${ }^{30}$

23 J. Kricher, The Balance of Nature: ecology's enduring myth (Princeton, NJ: Princeton University Press, 2009).

24 Native predators such as weka and harrier hawks did kill many rabbits, but did not count as 'natural enemies' under this definition, and as part of the 'inferior' native fauna, they were perceived to be inadequate for the task.

25 'Some attempt at compensation needed', Southland Times, 13 May 1874.

26 Dunlap, Nature and the English diaspora, 73.

27 R. Jefferies, The Gamekeeper at home (Oxford: Oxford University Press, 1978) [first published 1878].

28 Peter Holland and Guil Figgins, 'Environmental disturbance triggering infestations of gorse, rabbits and thistles in southern New Zealand: 1850 to 1980', International Review of Environmental History 1 (2015): 41-79.

29 L. E. Caltagirone and R. L. Doutt, 'The history of the vedalia beetle importation to California and its impact on the development of biological control', Annual Review of Entomology 34 (1989): 1-16.

30 Kricher, The Balance of Nature. 
The nineteenth century was a time of great confidence in the advances of the Western intellectual tradition. Exciting new laws of nature were being discovered in physics; so people asked at the time, why should not nature be equally well regulated? Actually, there was and is no guaranteed way to predict biological events comparable to the contemporary discoveries in the hard sciences: the results are always much more complicated in real life, as the history of rabbits and mustelids in New Zealand illustrates very well. ${ }^{31}$ Rather, we must understand the dynamic biological interactions between rabbits and their predators in the light of equally dynamic shifts in human assumptions about both, not in terms of simplistic assumptions about a static balance of nature. To see why the mustelids failed to save New Zealand's fledgling wool industry, we need a more detailed and critical historiography of this sorry story than has been attempted before. It needs to be based on a combination of specialist knowledge of the animals, an appreciation of the wider historical context, and access to previously untapped documentary resources.

Ferrets were easy to buy and import from breeders in the UK and Australia, and were the first 'natural enemies' to be tried in New Zealand. ${ }^{32}$ But neither ferrets raised for generations in comfortable hutches, nor pet cats stolen from cities, survived well when released into the wild over winter in the high country; some hardier enemy was needed.

By contrast, stoats and weasels $(M$. nivalis) are intractably wild animals, which evolved in the cold northern Holarctic as specialist predators of small rodents. ${ }^{33}$ Stoats in Britain are large enough to specialise in hunting rabbits, ${ }^{34}$ but too small to pose a serious threat to lambs, unlike the foxes that were already established in Australia. Stoats breed only once a year and are difficult to manage in captivity, but are common and easily trapped in the wild by skilled gamekeepers. The combination of ferrets, cats, stoats and weasels was seen by runholders as the most appropriate suite of natural enemies of the rabbit to bring to the unsettled high country, although vehement objections to the plan began immediately and continued long after it was too late to stop it. ${ }^{35}$

31 Carolyn M. King, 'The chronology of a sad historical misjudgement: The introductions of rabbits and ferrets in nineteenth-century New Zealand', International Review of Environmental History 3 (2017): 141-75.

32 King, 'The chronology of a sad historical misjudgement', 141-75.

33 Carolyn M. King and Roger A. Powell, The Natural History of Weasels and Stoats: Ecology, Behavior and Management, 2nd ed. (New York: Oxford University Press, 2007).

34 R. A. McDonald, C. Webbon and S. Harris, 'The diet of stoats (Mustela erminea) and weasels (Mustela nivalis) in Great Britain', Journal of Zoology 252 (2000): 363-71.

35 W. L. Buller, 'On the proposed introduction of the polecat into New Zealand', Transactions \& Proceedings of the New Zealand Institute 9 (1877): 634-5; H. B. Martin, 'Objections to the introduction of beasts of prey to destroy the rabbit', Transactions \& Proceedings of the New Zealand Institute 17 (1885): 179-82. H. Guthrie-Smith, Tutira. The Story of a New Zealand Sheep Station, 4th ed. (Wellington: A. H. \& A. W. Reed, 1969), 354. 


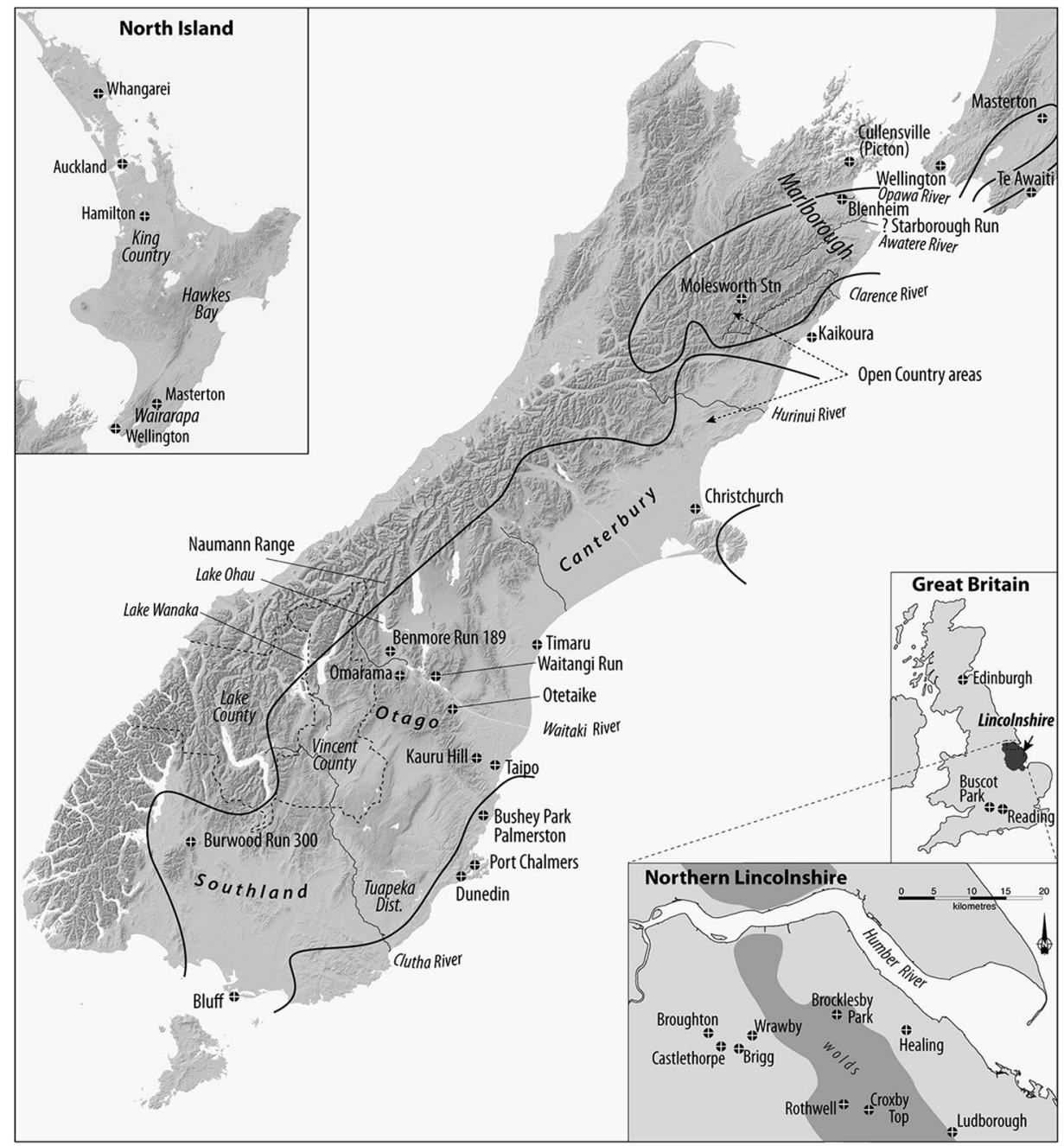

\section{Figure 1: Locations of places mentioned in the text}

Dark lines enclose the extent of open country, as defined by Holland and Figgins ('Environmental disturbance triggering infestations', 43), comprising the main area covered by pastoral runs and the favoured habitat for rabbits. For names, numbers and further descriptions of runs in Otago and Southland, see Robert Pinney, Early Northern Otago Runs (Auckland: Collins, 1981) and J. G. Sinclair, 'The Early Pastoral Runs of Otago and Southland', (Dunedin: The author, 2003). Inset, above left: North Island, New Zealand. Inset, lower right: Locations of places in the UK, with an enlargement for northern Lincolnshire, the centre of the former rabbit fur industry and of most of the mustelid collecting operations. Dashed lines enclose the boundaries of Vincent and Lakes Counties, which were among the areas worst affected by rabbits in the early 1880 s.

Source: Cartography by Max Oulton, from information collected by the author. 
Over the 10 years from 1883 to1892, multiple private and official shipments of stoats and weasels arrived from Britain, and the animals were released only in the most severely rabbit-infested upland areas. By the turn of the century, stoats and weasels were 'common in nearly every part of New Zealand, and in some enormously abundant ... They have not exterminated the rabbits, in most parts they cannot even keep them in check'. ${ }^{36}$

The aim of this paper is to review the documentary evidence on when, how, why and by whom stoats and weasels were collected and transported, at least to the extent that the original historical records still survive or can be deduced. The whole episode provides a well-documented example of how nineteenth-century notions about the inevitable human dominance over and control of the balance of nature and the effects of natural predation differ from those of today. Details of where the imported animals were distributed, and the pattern and timing of their subsequent spread, are described elsewhere. ${ }^{37}$

Primary sources detailing how the shipments were organised in the 1880s are preserved in archives and research libraries in New Zealand and in England, and in contemporary news reports, as discussed in earlier articles. ${ }^{38}$ The strong language used in these sources illustrates the intensity of the arguments of the time better than any subsequent summary. In addition I visited Brigg (Lincolnshire), the Museum of English Rural Life (Reading) and Buscot Park (Oxfordshire). In Brigg I was given access to a private collection of family papers, adding some key unpublished details relevant to the story.

Stoats and weasels are often confused, because both are small, brown-and-white, fastmoving, tube-shaped animals, and the distinguishing black-tipped tail of the stoat is not always noticed. ${ }^{39}$ Most of the primary sources cited here refer to both together, often under the general term 'weasels'; variant spellings ('weasle', 'weazel') are given here as in the original sources, to facilitate follow-up. Dates of ship departures from England and arrivals in New Zealand are taken from Comber's Index, which ends in December 1889. ${ }^{40}$

36 G. M. Thomson, The naturalisation of animals and plants in New Zealand (Cambridge: Cambridge University Press, 1922), 72.

37 Carolyn M. King, 'Liberation and spread of stoats (Mustela erminea) and weasels (M. nivalis) in New Zealand, 1883-1920', New Zealand Journal of Ecology 41 (2017): 163-77.

38 Carolyn M. King, 'Pandora's Box down-under: Origins and numbers of mustelids transported to New Zealand for biological control of rabbits', Biological Invasions 19 (2017): 1811-23; King, 'The chronology of a sad historical misjudgement', 141-75.

39 King and Powell, The Natural History of Weasels and Stoats.

40 W. C. Comber, 'Shipping to New Zealand, 1839 to 1889: Comber Index' (Wellington: New Zealand Society of Genealogists, 1985). 


\section{0-81: Weasels as saviours}

\section{The first proposals}

In Southland, about 30 people attended a meeting in May 1874 to discuss what might be done about the increasing numbers of rabbits. One speaker, R. J. Cuthbertson, was seriously alarmed by the universal prevalence of rabbits he observed in his travels around the district. ${ }^{41}$ He strongly recommended the introduction of weasels. The meeting voted in favour of the suggestion, and in 1876 the Rabbit Nuisance Committee of the New Zealand House of Representatives recommended that money should be granted for introducing weasels, which would '(if the object were attained) be of very great service'. ${ }^{42}$ The cautious wording shows that the committee was not yet convinced.

Cuthbertson and his business partner Macrorie ran a firm of stock and station agents and auctioneers, established in Invercargill in 1875. They anticipated a demand for weasels from Southland clients of their new business, and, since an official reply to a question in the House (19 July 1875) provided assurance that importing them was not already illegal, they wrote to Frank Buckland, an English naturalist and leading proponent of uninhibited acclimatisation. They proposed a plan to offer $£ 5$ per pair for English weasels, delivered alive to Bluff, and asked Buckland whether he thought such imports would be useful and feasible. ${ }^{43} \mathrm{He}$ replied that shipping weasels round the world to New Zealand would be impossible. Buckland recommended ferrets instead.

A Bill that would have made importing alien predators to attack rabbits illegal was passed by the House of Representatives, but stalled in the upper house, the Legislative Council. ${ }^{44}$ The decision to permit the imports was influenced by the membership of the Legislative Council, mostly representing the wealthy landed elite whose interests would benefit from the expected reduction in rabbit damage. It was also no doubt a relief to Dr Daniel Pollen of Auckland, who during the debate confessed to having 'some weasels in his possession'. 45

Pollen was not the only one who had been trying to import weasels privately, but bringing in a few of them was no solution to the problem if they could not establish a resident breeding population. Cuthbert Cowan, a leading Southland runholder,

\footnotetext{
41 'The Rabbit Nuisance', Southland Times, 6 May 1874.

42 S. Hodgkinson, 'Report of the Rabbit Nuisance Committee', AJHR I-5 (1876).

43 The incentive offered was about five times the average weekly wage for an English gamekeeper at the time (logicmgmt.com/1876/living/occupations.htm).

44 P. K. Wells, “An enemy of the rabbit”: The social context of acclimatisation of an immigrant killer', Environment and History 12 (2006): 269-96.

45 'Amendment to Protection of Animals Bill' [re banning imports of mustelids], New Zealand Parliamentary Debates (Wellington: Government Printer, 1876), 273.
} 
told the Rabbit Nuisance Committee that 'they are bad travellers ... [but] I have some coming out. They were to have been dispatched in July'. ${ }^{46}$ Almost a decade later, Cowan stated that 'I landed 3 weasels and put them out on my own property ... Nothing has been seen of them'. ${ }^{47}$

Another runholder affected by the crisis was Robert Campbell, a member of a wealthy family-run mercantile business, with branches in India and Australia. ${ }^{48}$ He came to New Zealand in 1859 from Buscot Park, near Oxford (Figure 1, inset), where his father, Robert Tertius Campbell, and his eldest brother, William Henry Campbell, still lived. Robert was a member of the Legislative Council from 1870 to 1889 , and used his position to speak strongly on rabbits. Several English newspapers announced in October 1876 that 'a large number of live stoats collected from various English counties' were about to be shipped to New Zealand by William Campbell. The notices do not say the stoats were destined for Robert's rabbit-infested runs, and no documentary confirmation has yet emerged, but it would be surprising if they were not.

The idea of exporting weasels to New Zealand was debated for months during 1876, both in the British press and in New Zealand. It provoked a passionate response from leading ornithologists concerned with the threat to New Zealand's endemic flightless native birds, represented in England by Professor Alfred Newton of Cambridge University, and endorsed in New Zealand by Walter Buller, ${ }^{49}$ among others. For different reasons, opposition was also strongly expressed by landowners who had been investing heavily in acclimatising game birds for sport, or were worried about predation on lambs: 'the introduction of such inveterate destroyers, not only of poultry and game, but also lambs, is most objectionable', declared the Otago Witness of 17 June. Both sides of the debate were summarised in a long article in a British naturalists' journal (Land and Water, edited by Frank Buckland) and reprinted in the Otago Witness. ${ }^{50}$ It ended by Buckland reluctantly conceding Newton's point and withdrawing his support for the idea.

Meanwhile, New Zealand's agent general in London was sufficiently alarmed by William Campbell's proposal to address a separate official enquiry to Professor Newton 'as to the necessity of proceeding to such extreme measures'. Newton repeated his opposition in forceful terms, adding that 'there is no gamekeeper in this country who does not wage incessant war against them'. ${ }^{51}$ Such firm official disapproval of an action that could be linked to Robert Campbell, a serving

46 Hodgkinson, 'Report of the Rabbit Nuisance Committee'.

47 G. Randall Johnson, 'Report of the Joint Committee on Sheep and Rabbit Acts', AJHR 1884 I-5 (1884).

48 D. C. McDonald, 'Campbell, Robert 1843-1889', in Dictionary of New Zealand Biography, ed. C. Orange

(Wellington: Bridget Williams Books / Department of Internal Affairs, 1993), 2:74.

49 Buller, 'On the proposed introduction of the polecat into New Zealand', 634-5.

50 'Weazels for New Zealand', Otago Witness, 9 December 1876, 21.

51 Agent General, 'Methods for diminishing the rabbit nuisance', AJHR H-2 I (1877). 
member of the Legislative Council, might have been embarrassing. The evidence so far available includes no archive recording William Campbell's cargo arriving at Bluff in the late 1870s. Whether or not any unrecorded shipments arrived, rabbits continued to ravage the South Island runs.

Professional rabbiters and gamekeepers in Britain quickly recognised the new employment opportunities offered by the demand for their skills in New Zealand. For example, James Sellwood, a gamekeeper from Gloucester, emigrated with his family in the Oamaru in $1876 .{ }^{52}$ There were many others. For at least the next couple of years, William Campbell encouraged the idea, by placing repeated advertisements recruiting or encouraging rabbit trappers to emigrate. Rabbits continued to outbreed them all.

\section{Gloomy predictions}

The runholders' view of their future was approaching desperation. The Marlborough Express $^{53}$ predicted that, since no amount of human effort could prevent the spread of rabbits, only the importation of stoats, weasels and ferrets in large numbers could prevent the collapse of the wool industry (then earning 30-40 per cent of the colony's export income $)^{54}$ within the next 10 years.

However great the need, it was simply not possible to do that then. Public opposition had already persuaded Buckland to back down from his advocacy of the proposed imports in 1876, and both Macrorie and Cuthbertson died within a few years of establishing their partnership. Cuthbertson's own brother R. F. Cuthbertson stated in evidence to the Rabbit Nuisance Committee in 1881 that, some years ago he had tried to import ' $£ 500$ worth of vermin, but failed to get any at all'. 55

The science of invasion biology confirms that the success of a deliberate introduction depends largely on the size of the colonising group, ${ }^{56}$ which suggests that the few weasels obtained by Cowan and Pollen did not amount to a viable propagule. Neither, apparently, did two weasels landed by Joseph Ward of Wairau among a consignment of ferrets. ${ }^{57}$ It seems as if no one in the late 1870 s had worked out how to bring such highly strung and aggressive animals alive and healthy round the world, in numbers sufficient to establish a viable population.

52 Passenger list for Oamaru Sep.-Dec. 1876. R4085494 Im 15/278, Archives New Zealand, Wellington.

53 'Our Kaikoura Letter' [Stoats and weasels needed to save NZ wool], Marlborough Express, 25 July 1877.

54 Registrar General's Office, Statistics of the Colony of New Zealand for the years 1870 to 1899 [Blue Books] (Wellington: Government Printer, 1870-99).

55 Anon., 'Report of the Rabbit Nuisance Committee' [1880-81], AJHR I-6 I (1881).

56 T. M. Blackburn, J. L. Lockwood and P. Cassey, 'The influence of numbers on invasion success', Molecular Ecology 24, no. 1 (2015): 1942-53.

57 Anon., 'Report of the Rabbit Nuisance Committee' [1880-81], AJHR I-6 I. 
Disappointed Marlborough runholders continued trying to make their own arrangements. Many landholders urged the official introduction of stoats and weasels, citing cases in Britain where rabbits (a valued animal there) could not be kept until the ground was cleared of stoats. An 1881 motion to a meeting of Marlborough landowners, proposing a subscription levied on all sheep owners between the Opawa and Clarence rivers (Figure 1) to finance a large collective importation of the natural enemies of rabbits was fiercely debated, and lost. A Blenheim stock agent placed advertisements offering to pay stewards on wool ships $£ 1$ each for stoats and weasels landed alive..$^{58}$ Judging by the much greater expense and expertise required to ensure the success of the later importations, any unfortunate animals had small chance of surviving the journey in such inexperienced hands.

Another enterprising party, signing himself only 'Colonist', had a letter published on 14 October 1882 in The Field, asking if any readers could supply information as to the means of procuring stoats, polecats or weasels, with suggestions for their care during transport to New Zealand. The editor appended a warning that such animals would not confine their attentions to rabbits; well-intentioned gentlemen should consider more carefully the likely results of their experiments. The letter provoked several replies, including one from Newton, agreeing on the danger and advising 'Colonist' to think again. One correspondent pointed out that it would be better to send out professional rabbit catchers with plenty of long nets than to add more enemies to the poor kiwis. Would not the authorities prohibit the introduction of these vermin before it is too late? On the contrary, before long it would be the authorities who were promoting them.

\section{The acclimatisation societies}

The regional acclimatisation societies were sharply divided. Otago viewed the proposals with deep regret; Hawke's Bay found itself at loggerheads with rabbit inspectors; Canterbury thought the imports should be illegal. Only Southland dismissed their objections, pointing out that other districts were not suffering from rabbits as Southland was. Contrary to popular assumption, the societies were not entirely responsible for the regrettable decisions of the time, and 'even when they were, their goals generally reflected what people of the time wanted ... The general view was that change was inevitable and could not be stopped'. ${ }^{59}$

Updated versions of the original Rabbit Nuisance Act 1876 and its later amendments added responsibility for rabbits to the work of existing sheep inspectors, provided for legal protection for all enemies of the rabbit, and applied to the whole country. It caused particular outrage when, within 20 years, stoats and weasels spread into

58 'Advertisements: To Stewards and others of wool ships \&c.', Evening Post, 14 December 1881, 3.

59 McDowall, Gamekeepers for the nation, 36. 
areas where there were no rabbits. ${ }^{60}$ Complaints from the settlers, that this illogical provision prevented them from destroying predators to protect their cherished poultry and game birds, produced only a terse official notice from John McKenzie, Minister for Agriculture, drawing attention to the provisions of the Act protecting the natural enemies of the rabbit, listed as ferrets, cats, stoats, weasels and mongooses. The Auckland and Tauranga acclimatisation societies tried several times to persuade the minister to permit the removal of protection for stoats and weasels in districts not infested with rabbits. He replied that 'we cannot exempt a single district' ${ }^{61}$

As a long-term result of this ongoing conflict of interests, the operations of acclimatisation societies became, as the Otago Witness reported sorrowfully in December 1907, largely restricted to fish culture-especially trout and salmon, whose impact on native freshwater ecosystems paralleled that of rabbits on pastures and native fauna, although that was not known at the time. The Council of the Otago Acclimatisation Society agreed in 1909 that 'the importation of ferrets, stoats, and weasles into New Zealand was a disastrous mistake, owing to game being destroyed'. ${ }^{62}$ By that time, recognition of the need to protect the native species was rapidly increasing, but for some, concern about wasted investment in introduced gamebirds was still stronger.

\section{Benjamin Bayly}

The Superintending Inspector responsible for controlling rabbits, Benjamin P. Bayly, appointed in $1881,{ }^{63}$ tabled his first report in 1882 , describing the establishment of his administration and the ongoing importations of ferrets. He added cautiously: 'Other enemies, such as the stoat and weasel may be introduced, if found practicable'. ${ }^{64}$ Bayly strongly believed that the introduction of stoats and weasels was a legitimate function of the legislature, because it would rehabilitate the millions of acres of crown lands now abandoned as worthless. He considered that stoats and weasels would be better adapted to cold weather than were ferrets or pet cats, and less vulnerable to canine distemper. In the face of repeated and increasingly hostile correspondence and news coverage, and questions in the House, Bayly repeated that he was 'a thorough believer in the natural enemy' and was determined to continue recommending their ongoing introduction. ${ }^{65}$ Parliament ignored the outcry, and not only commissioned many imports itself, but also announced that it would 'assist liberally' private enterprises doing the same.

60 King, 'Liberation and spread of stoats and weasels', 163-77.

61 [Complaints about natural enemies], 1896-98. R1762009, Archives NZ, Wellington.

62 'Stoats and weasels', Waihi Daily Telegraph, 27 March 1909.

63 Anon., 'Notices' [Appointment of B. P. Bayly], New Zealand Gazette, 18 November 1881, 2.

64 B. P. Bayly, 'Livestock and Rabbits (Report as to Rabbits)', AJHR H-21 (1882).

65 Correspondence protesting [against the] introduction of stoats and weasels, 1886. R24456501, Archives NZ, Wellington. 


\section{2: Samuel Grant and the Brigg connection}

The prospects of successfully introducing wild stoats and weasels depended on one important condition: the recruitment of a skilled man with sufficient knowledge of these animals to collect them from Britain, feed and house them, and then convey them alive to New Zealand. The trade was a new one, because there had never before been any demand for such unusual articles of commerce. Fortunately, Lincolnshire gentleman farmer Grant was familiar with New Zealand, ${ }^{66}$ and was also able to facilitate the right contacts. Brigg, in Lincolnshire (Figure 2), was a local centre of the nineteenth-century rabbit-warrening and fur-dressing industry. ${ }^{67}$ In England at that time, rabbits were an important economic harvest, ${ }^{68}$ so they were provided with artificial warrens to encourage breeding, and protected by networks of traps set to remove the stoats and weasels that competed with the farmers for rabbits. Grant owned a farm at Castlethorpe, $1.8 \mathrm{~km}$ from Brigg, and employed local lads to help work the traps. Warrens were especially common around Brigg and on the Lincolnshire Wolds. ${ }^{69}$ The late nineteenth century was also the heyday of the aristocratic sporting estate, where gamekeepers were employed to remove stoats and weasels (and other predators) that destroyed many game birds. ${ }^{70}$

Grant had been conducting a long correspondence with Charles de Vere Teschemaker about their common interests in rabbit control. ${ }^{71}$ Teschemaker part-owned a run at Kauru Hill, ${ }^{72}$ and had certainly hosted Grant and Foster during their 1880 tour of the South Island at his family homestead at Taipo; ${ }^{73}$ so probably did Rich at Bushey Park, $48 \mathrm{~km}$ from Taipo (Figure 1). Rich was a staunch member of the Otago Acclimatisation Society, and one of few who had spoken strongly against the idea of introducing rabbits into Otago. ${ }^{74}$ In 1882, he commissioned Grant to supply a shipment of mustelids for Bushey Park, with an experienced man to accompany them on the journey from England. ${ }^{75}$ It was the first of at least 25 shipments carrying at least 7,838 weasels and stoats to New Zealand over the next 10 years. $^{76}$

\footnotetext{
66 Grant and Foster, New Zealand.

67 F. Henthorn, A history of 19th century Brigg (Stamford, Lincs: Spiegl, 1987); J. Bygott, Lincolnshire (London: Robert Hale, 1952).

68 H. V. Thompson and C. M. King, eds., The European Rabbit: The History and Biology of a Successful Colonizer (Oxford: Oxford University Press, 1994), 64-7.

69 T. W. Beastall, The Agricultural Revolution in Lincolnshire (Lincoln: History of Lincolnshire Committee, 1978).

70 R. A. McDonald and E. C. Murphy, 'A comparison of the management of stoats and weasels in Great Britain and New Zealand', in Mustelids in a modern world, ed. H. I. Griffiths (Leiden: Backhuys, 2000), 21-40.

71 C. de V. Teschemaker, B. P. Bayly and Colonial Secretary, Correspondence concerning Teschemaker, 1884; C. de V. Teschemaker to Major Atkinson [NZ Premier] on obtaining information on stoats and weasels, 1883. R24413234, Archives NZ, Wellington.

72 Pinney, Early Northern Otago Runs.

73 Samuel Grant to Major Teschemaker, 1883. R24413234, Archives NZ, Wellington.

74 'The introduction of rabbits', Otago Daily Times, 2 August 1867.

75 Samuel Grant to Major Teschemaker, 1883. R24413234, Archives NZ, Wellington.

76 King, 'Pandora's Box down-under', 1811-23.
} 


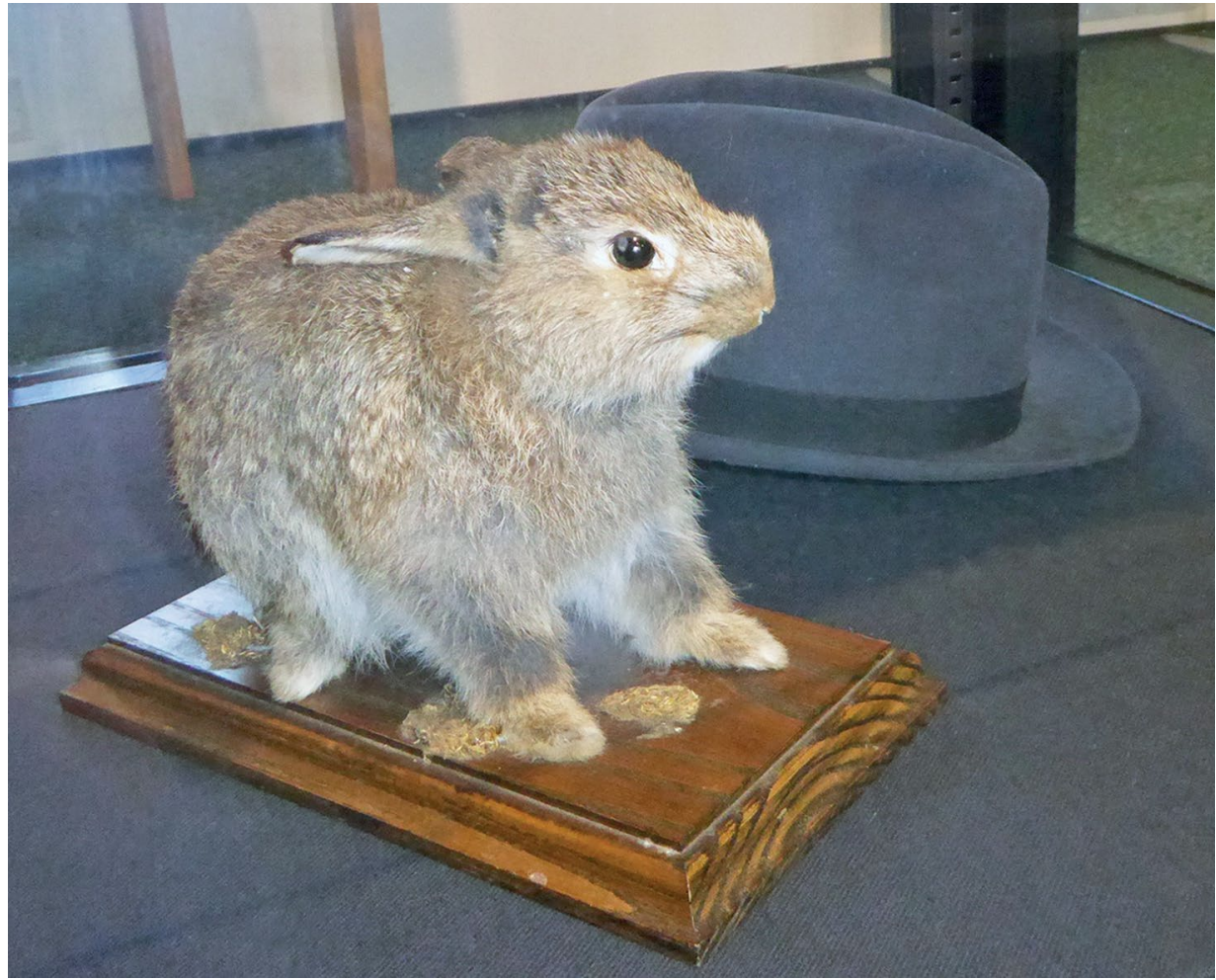

Figure 2: A display in the Brigg Heritage Centre celebrating the importance of rabbits to the local economy during the eighteenth and nineteenth centuries. Rabbit fur traded through the Brigg market was used to trim gloves and muffs, and to make the felt needed for trilby hats

Source: Author's private collection.

\section{3-91: How the importations were organised}

\section{The couriers}

The Allbones family were professional vermin destroyers based in Brigg. Mathew Henry Allbones (1836-1909; known as Henry) had been a gamekeeper on the earl of Yarborough's estate at Brocklesby Park, $16 \mathrm{~km}$ from Brigg, and his eldest son Walter Allbones (1863-1948), had learned the art of trapping on Grant's Castlethorpe farm. Henry was described as 'in appearance and manner the very "spit" [spitting image] of a professional vermin-catcher' ${ }^{77}$ Both father and son were especially knowledgeable about stoats and weasels, and had proven themselves to be

77 'The Government Vermin-catcher', Marlborough Express, 21 July 1885, 2. 
reliable and responsible employees. Grant recommended Walter as the right man to deliver the first consignment of stoats and weasels to Rich. (One of the acute ironies of this story is that the Allbones' expertise in vermin trapping, recruited to help New Zealand farmers remove introduced rabbits, had been gained in the course of their work in protecting English rabbits!)

Over the 10 years of the importation program, Walter undertook at least five deliveries to New Zealand, and Henry at least seven. At first, Henry collected stock in England while Walter accompanied the shipments. On at least two occasions Walter took along an assistant, his friend Fowler Metcalf, a gamekeeper employed at Broughton Lodge near Brigg (Figure 1, inset). In October 1886, Walter married his fiancée Annie and settled down in Brigg to produce a large family, swapping roles with his father. Henry Allbones last appeared in the passenger records in May 1890, when he arrived in the Tongariro with his third son, Henry junior.

The three Teschemaker brothers (William and Charles in New Zealand and Major Thomas in England) had been instrumental in organising the first trial shipment of stoats and weasels to Rich's estate in $1882-83 .^{78}$ Charles continued to take a great interest in how to improve the business of importing natural enemies of the rabbits, and as soon as the government started making official contracts, he wanted to take part. He had no direct field experience with these animals, but he disputed Allbones' insistence on the extra expense of carrying live pigeons and their food during the voyage (Table 1). In September 1884 he persuaded the colonial secretary to authorise him to make enquiries in England, and to engage a man to collect and transport 100 stoats and weasels on Teschemaker's own terms. ${ }^{79} \mathrm{He}$ planned to cut costs by replacing the courier's authorised wage of 30s a week with payments of $2 \mathrm{~s}$ a head for animals delivered to the ship, plus (as before) $5 \mathrm{~s}$ a head for animals landed, and reducing the on-board feeding bill by supplementing pigeons and corn with rabbits and hay, plus frozen meat (Allbones believed that stoats and weasels would not eat even dead pigeons, never mind frozen meat). The man Teschemaker chose, not an experienced gamekeeper, proposed to collect and transport 300 animals more cheaply per head than 100-far more than had been attempted before. ${ }^{80}$ Bayly wrote a wry comment on the file suggesting that Teschemaker had overestimated the number that could be cared for in one shipment, but that he could do what he liked within the authorised expenditure.

78 C. de V. Teschemaker to Major Atkinson [NZ Premier] on obtaining information on stoats and weasels, 1883; C. de V. Teschemaker, B. P. Bayly and Colonial Secretary, Correspondence concerning Teschemaker, 1884. R24413234, Archives NZ, Wellington.

79 Teschemaker, Bayly and Colonial Secretary, Correspondence concerning Teschemaker, 1884. R24413234, Archives NZ, Wellington.

80 Teschemaker, Bayly and Colonial Secretary, Correspondence concerning Teschemaker, 1884. R24413234, Archives NZ, Wellington. 
The frequent consignments must have often needed the help of other agents. Immediately after the 1885 publication of reports on the success of Walter's first official consignment on the Doric (Table 2), a syndicate of runholders was formed to employ Allbones to bring out a private shipment. Beaten by the competition, the government had to employ 'another agent for similar purpose' ${ }^{81}$ He could have been the unnamed man who arrived in the Ionic in October $1885,{ }^{82}$ the third of five shipments to arrive within a few months, and the first that was probably not escorted by either of the Allbones. The records also include enigmatic references to a man who in July 1883 was already on his way to England to collect animals; ${ }^{83}$ and to Teschemaker's man, who was supposed to be sending out a consignment in the northern spring of $1885 ;{ }^{84}$ but I have found no confirmation of either.

One of few alternative agents to be named was George D. Storey from Cullensville, a small town west of Picton (Figure 1), who was employed by the Awatere Rabbit Board to bring a consignment on the Ionic in July 1888, and probably a second lot later. Most shipping records do not mention the animals, and often not the names of steerage passengers, but Customs records report many more animals imported than could have been carried in the 25 known shipments. Tracing unspecified consignments would be nearly impossible without the name of the accompanying agents.

\section{Collecting and transporting the animals}

To collect animals for export, Walter Allbones and his father Henry first persuaded friends and local contacts working in the gamekeeping trade at Castlethorpe, Broughton, Brocklesbury Park and Croxby Top (Figure 1, inset) to switch to box traps or stop-snares instead of leg-hold traps. Handbills offering to buy live animals were distributed throughout north Lincolnshire, and advertisements placed in local newspapers. ${ }^{85}$ As demand grew, Henry was able to claim that he had been permanently appointed by the government of New Zealand to collect weasels and stoats for export, so he began to advertise in other county papers, such as the Grantham Journal, Sheffield Daily Telegraph, Fife Free Press and Yorkshire Post, offering to supply traps at $3 \mathrm{~s} 6 \mathrm{~d}^{86}$ and instructions if required. He paid $6 \mathrm{~s}$ each for stoats and $4 \mathrm{~s}$ each for weasels, plus carriage, provided they were sound and healthy. W. Acton Adams of Molesworth Station later pointed out one stoat was worth two weasels

81 B. P. Bayly, 'Annual Report on the Rabbit Nuisance [1884-85]', AJHR H-16 (1885).

82 'Annual Report on the Rabbit Nuisance' [1885-86], AJHR H-19 (1886); [NZ] Colonial Secretary to Colonial Secretary for NSW: details and costs of importing stoats and weasels to New Zealand, 1885. R24418540, Archives NZ, Wellington.

83 B. P. Bayly, 'Annual Report on the Rabbit Nuisance' [1882-83], AJHR H-18 (1883).

84 Teschemaker, Bayly and Colonial Secretary, Correspondence concerning Teschemaker, 1884. R24413234, Archives NZ, Wellington.

85 The Field, 6 December 1884.

86 i.e. three shillings and sixpence. For definitions of monetary units, see Table 1. 
in killing rabbits, ${ }^{87}$ so suggested paying an extra $5 \mathrm{~s}$ for stoats. Allbones increased his purchase price to $7 \mathrm{~s} 6 \mathrm{~d}$ for stoats, and some advertisements specified 'No more weasels wanted'. Still, many more weasels than stoats were brought in. ${ }^{88}$

Henry and Walter developed a system for managing large numbers of stoats and weasels on the long journey, based on the assumption that the diet of these active small predators required fresh blood at least as often as meat. This was a common perception at the time, derived from widely reported observations that a stoat or weasel entering a henhouse or chick run would kill every bird in sight, leaving nearly all of them as uneaten carcases with needle-point punctures in the neck.

Such behaviour had been an important adaptive strategy for the ancestors of small mustelids that evolved to live on fluctuating populations of voles and lemmings in the frozen north of Eurasia. It allowed them to collect and cache surplus food during years when hunting was easy, which in that cold climate stayed fresh enough to eat during the starvation years that followed. In other contexts, the same bloodthirsty behaviour seemed either inexplicably wasteful, or just what was needed, depending on the point of view. Ornithologists and keepers of game birds condemned stoats and weasels as the most destructive of all four-footed vermin. Runholders desperate for an ally against the rabbits praised their love of slaughter.

Among the early objections to attempts to importing stoats and weasels round the world was the prediction that such small, active animals could not endure confinement in small cages for months at a time, because 'they knock themselves to pieces about the sides of the cage' ${ }^{89}$ But the Allbones' system proved that the little animals were remarkably tough, and if supplied with a dark nest box filled with dry bedding, and kept clean and well fed on fresh meat still containing blood, carried on the ships as live pigeons, plus plenty of water, the mortality rate during the journey was consistently (with rare exceptions) under 10 per cent.

Henry's system of collecting and managing the animals illustrates the care and effort required. He explained the full details to a journalist in $1887 .{ }^{90}$ His account explains why organising the shipments required some highly specialised skills, and suggests why rival attempts to manage the shipments more cheaply, or by inexperienced couriers, had less chance of succeeding. The keys to his success were careful vetting of the animals offered (he took only the most vigorous and uninjured individuals); he allowed a generous ration of live pigeons to feed them on, at the rate of 4,000 per

87 'Awatere Rabbit Board', Marlborough Express, 5 February 1889, 3.

88 King, 'Liberation and spread of stoats and weasels', 163-77.

89 Hodgkinson, 'Report of the Rabbit Nuisance Committee'.

90 This account was published in The Weekly Press on 20 May 1887, and syndicated four days later with extra details in the Mataura Ensign, under the heading 'Stoats and Weasels: An Interview with an Expert'. 
shipment of 300 stoats and weasels $;{ }^{91}$ certainly no cold meat of any sort; and strong, zinc-lined travel boxes kept scrupulously clean and dry throughout the voyage. Three animals occupied each box, presumably separated by internal compartments, and between them the three residents ate one pigeon per day per box.

Allbones' expert services did not, of course, come cheap (Table 1), but the animals he brought were valuable to runholders, and competition for them was stiff. The Auckland Star of 28 January 1885 reported that, when 20 weasels and six stoats from the Ionic were sold at a Christchurch auction, the weasels fetched $£ 3$ each, and the stoats $£ 55 \mathrm{~s}$ each. Such high prices created quite a sensation: some English newspapers reported with astonishment that 'these animals, which have hitherto been looked upon as vermin, now ... possess a marketable value'; others suggested that, as 'farmers are making $6 \mathrm{~s}$ and $4 \mathrm{~s}$ a head ... the trade is likely to become quite an opening for distressed agriculturalists' (conventional farming in England at the time was barely, if at all, profitable). Naturalists in England merely predicted that '[d] oubtless we shall hear in a few years that the New Zealanders are at their wit's end to devise means for getting rid of weasels'..$^{2}$

Henry's methods were expensive, but well justified because he could handle large consignments with minimal losses. But he dropped out of the trade in 1890, and other couriers were less careful, or were under more pressure to cut costs. Both Charles Teschemaker and Acton Adams had disputed the need to feed the animals in transit on fresh pigeons, suggesting frozen mutton would be much less trouble and greatly reduce the landed cost. ${ }^{93}$ In Henry Allbones' absence, three of the six shipments sent in 1891 to the Wairarapa Rabbit Board recorded drastic mortality rates.

Allbones sometimes had to respond to uninformed criticism, especially to sensational and inaccurate reports that the pigeons were fed to the weasels alive. As he pointed out, that would be completely impractical, as they would flap violently about the cages, and upset the water tins and everything else. There was no more cruelty involved than in the eating of a pigeon pie, which at that time was a common dish in rural England.

\footnotetext{
91 Henry was adamant that it was necessary to feed the animals on fresh meat, still warm, even though he sometimes had to defend his operation against public sympathy for the pigeons: [Poor pigeons], Leamington Spa Courier, 2 June 1888.

92 'An Anti-ferret Testimony', Marlborough Express, 21 April 1885, 3.

93 Teschemaker, Bayly and Colonial Secretary, Correspondence concerning Teschemaker, 1884. R24413234, Archives NZ, Wellington; 'Awatere Rabbit Board', Marlborough Express, 5 February 1889, 3.
} 
Table 1: Costs of two representative Allbones contracts

\begin{tabular}{|c|c|c|c|}
\hline \multicolumn{2}{|l|}{ Rich, 23 Nov. 1883 (A) } & \multicolumn{2}{|l|}{ Riddiford, May 1885 (B) } \\
\hline Item & Cost & Item & Cost \\
\hline Wages, 20 weeks @ £1.5 & $£ 30$ & WA@£35.5, assistant @ £7 & $£ 42.5$ \\
\hline Passages & $£ 50$ & $\begin{array}{l}\text { Home } \\
\text { Back }\end{array}$ & $\begin{array}{l}£ 21 \\
£ 17\end{array}$ \\
\hline 100 animals & $£ 25$ & $\begin{array}{l}182 \text { weasels, } 66 \text { stoats } \\
\text { Labour to collect } \\
\text { Feeding before shipment }\end{array}$ & $\begin{array}{l}£ 84.9 \\
£ 16.5 \\
£ 135.75\end{array}$ \\
\hline Pigeons, 110 dozen @ £0.45* & $£ 45.5$ & $\begin{array}{l}2750 \text { pigeons } \\
\text { Add } 450\end{array}$ & $\begin{array}{l}£ 120.2125 \\
£ 19.6875\end{array}$ \\
\hline Pigeon boxes, 22 @ £0.05. & $£ 1.1$ & & \\
\hline Weasel boxes, $30 @ £ 0.50$ & $£ 15$ & $\begin{array}{l}\text { Tarpaulins } \\
\text { Deck housing }\end{array}$ & $\begin{array}{l}£ 8.8583 \\
£ 54.15\end{array}$ \\
\hline Corn for pigeons & $£ 37.5$ & Corn for pigeons & $£ 42.2250$ \\
\hline Water troughs & $£ 2$ & & \\
\hline Railway charges & $£ 10$ & $\begin{array}{l}\text { Freight } \\
\text { Shipping }\end{array}$ & $\begin{array}{l}£ 94.5 \\
£ 6.2125\end{array}$ \\
\hline Bonus of $£ 0.5$ on all landed & $£ 25$ & $\begin{array}{l}\text { Bonus } 167 \text { weasels @ } £ 0.2555 \\
\text { stoats @ £0.35 }\end{array}$ & $\begin{array}{l}£ 41.75 \\
£ 19.5\end{array}$ \\
\hline Correct error in cost pigeon boxes & $£ 4$ & $\begin{array}{l}\text { Sundry } \\
\text { Travel expenses }\end{array}$ & $\begin{array}{l}£ 69.4208 \\
£ 6.4\end{array}$ \\
\hline Totals & $£ 245.1$ & & $£ 773.77$ \\
\hline
\end{tabular}

(A) as a prediction of future costs compiled by Rich, extrapolated to 100 animals from his $1882-83$ experience with the Waitangi (Outwards Letterbook-Agent General. Colonial Secretary to Agent General [re Allbones commission], 4 December 1883. R20557923, Archives NZ, Wellington), and (B) actual costs for 248 animals collected, 222 delivered, as listed in the colonial secretary's account to E. J. Riddiford, to which the agent general added further charges, bringing the total due to $£ 803$ (Colonial Secretary and E. J. Riddiford, Correspondence re accounts for Rimutaka shipment, 1885. MS574-006, Riddiford Family Papers, Alexander Turnbull Library, Wellington). *Original incorrect: actual cost of pigeons $£ 49.5 .^{94}$

\section{The clients}

Despite the costs, the demand for stoats and weasels came from both the wealthy and the desperate. In 1883, the first shipment was paid for privately by Rich. In 1885 , one of the largest consignments to that date was sent to Edward J. Riddiford, a prominent Wellington politician and runholder of the southern North Island. He shared the order with Cyrus Goulter of Marlborough, which arrived in the Rimutaka in July 1885 . Of 236 animals sent off ${ }^{55}$ in their 80 custom-built,

94 Monetary amounts are cited in the currency of New Zealand used in the nineteenth century, the British pound sterling ( $($ )), divided into 20 shillings (s), each of 12 pence (d). The sub-units within Table 1 have been converted into decimals of pounds. The Reserve Bank of New Zealand provides an online calculator by which prices back to 1862 can be converted into contemporary New Zealand dollars: www.rbnz.govt.nz/monetary-policy/inflationcalculator.

95 [NZ] Colonial Secretary to Colonial Secretary for NSW: details and costs of importing stoats and weasels to New Zealand, 1885. R24418540, Archives NZ, Wellington. 
zinc-lined maritime lodgings, accompanied by 4,000 live pigeons and 42 quarters of avian shipboard rations, 222 arrived in good condition, and only 14 died on the passage. As these animals were being distributed across Riddiford's Te Awaiti station, Riddiford and Henry Allbones sat down at the homestead and signed another contract (Figure 3), commissioning a second consignment, on the same terms as the first.

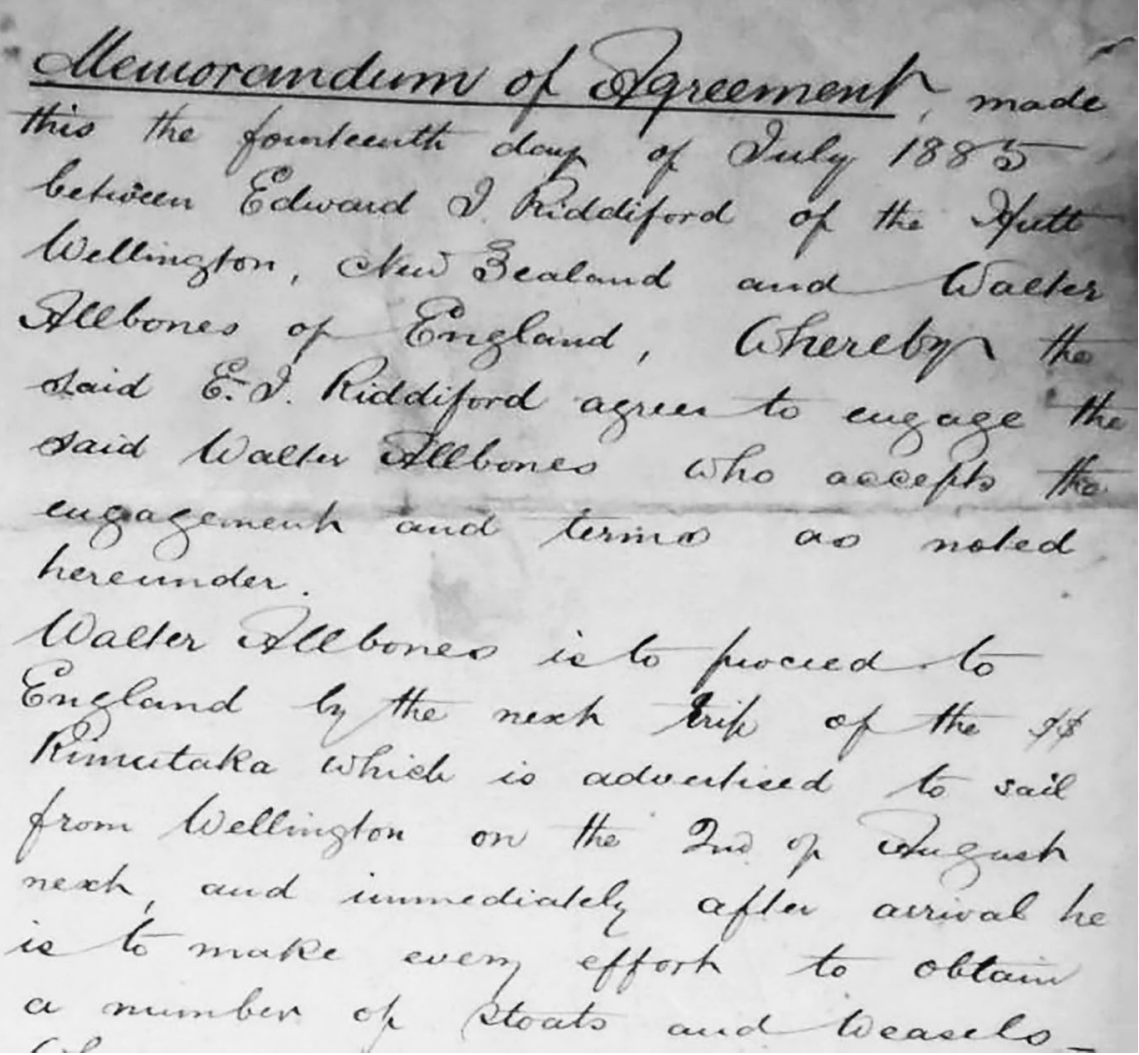

Figure 3: First page of E. J. Riddiford's second contract commissioning Walter Allbones to bring a shipment of stoats and weasels, dated 14 July 1885

Source: D. Allbones private collection, Brigg, Lincolnshire.

The problem of financing the imports was still a serious brake on Bayly's program. In July 1887, Robert Campbell tried to persuade the Colonial Secretary Patrick Buckley to subsidise private imports of stoats and weasels at the rate of $£ 2$ to $£ 1 .{ }^{96}$ Campbell ordered a shipment of about 300 stoats and weasels as a public service, confident that 'these, followed by more as I can manage, will keep the rabbits out of Canterbury'. The minister's office confirmed to Campbell that he would authorise

96 Robert Campbell and Colonial Secretary, Correspondence concerning the promised subsidy for importing the natural enemy, 1887. R17620769, Archives NZ, Wellington. 
the payment of half the expense of consignment, ${ }^{97}$ in order to 'encourage private enterprise in importing stoats and weasels'. From October 1887 to the end of 1891 , the annual lists of living animals imported ${ }^{98}$ distinguished stoats and weasels as a separate category, totalling 6,516 animals, until the category was abolished in 1892.

As soon as it was known that the government would subsidise private importations, the runholders were quick to apply. The Rabbit Inspector in Dunedin (E. Clifton) reported that private individuals in the Tuapeka District alone were so anxious to obtain these animals that half the cost of importing 1,000 stoats and weasels would be immediately guaranteed. On 28 November, Clifton forwarded orders to purchase 1,475 animals at the subsidised rate. ${ }^{99}$

The colonial secretary organised government orders for the high country between 1884 and 1886. In 1885 William Stronach of Lake Ohau Station, fearing that the rabbits would soon overrun the whole of Otago, begged for a supply of natural enemies, the only hope of stopping the rabbit invasion in such wild country: 'Let us have them in sufficient numbers' ${ }^{100}$ Stronach's idea of 'sufficient numbers' was certainly an order of magnitude greater than the hundreds distributed so far.

Consortia of runholders, impressed by Bayly's 1886 report asserting that, at the 1884 release area in Lake Wanaka, '8000 acres [3,237 ha] of badly infested country was cleared for about $\mathfrak{E 5 0 0 ’}{ }^{101}$ pleaded for allocations from official shipments. A formal petition to the colonial secretary, signed by all the owners and managers of the famous stations of the Waitaki, ${ }^{102}$ expressed their concerns in strong language:

We the undersigned ... would most earnestly beg to draw the attention of the Government to the urgent necessity of taking [the] immediate action of introducing large numbers of the natural enemy of the rabbit ... [we fear] the fate of the back runs in the Lake and Vincent Counties ... [We] are certain that in the natural enemy alone remains ... the only means to avert the calamitous result of a wholesale abandonment of runs ... at no very distant period. ${ }^{103}$

97 E. Clifton, 'Correspondence concerning the promised subsidy for importing the natural enemy', 1887. R17620769, Archives NZ, Wellington.

98 Registrar General's Office, Statistics of the Colony of New Zealand for the years 1870 to 1899 [Blue Books].

99 E. Clifton, 'Correspondence concerning the promised subsidy for importing the natural enemy', 1887. R17620769, Archives NZ, Wellington.

100 Correspondence concerning natural enemies for Lake Ohau Station, 1885. R24418111, Archives NZ, Wellington.

101 Bayly, 'Annual Report on the Rabbit Nuisance' [1885-86].

102 Pinney, Early Northern Otago Runs.

103 [Runholders of Upper Waitaki], Correspondence on the state of the rabbit scourge in upper Waitaki, 1887.

R17620769, Archives NZ, Wellington. 
Thomas Middleton (Campbell's manager) wrote on 4 March 1887 to John Wilson (Campbell's London agent) that ' $[w] e$ are urging the Government to get out stoats in thousands' [my italics]. ${ }^{104}$

Rabbit boards ordered large shipments in later years. The Wairarapa Rabbit Association offered to pay $£ 500$ for 250 stoats and weasels by the end of January 1887 if 75 per cent of the shipment were stoats and all were landed in good condition-plus 2 s $6 \mathrm{~d}$ per stoat. They were even willing to add another $£ 500$ for a later shipment. ${ }^{105}$ The Awatere Rabbit Board, established in 1886 in Marlborough province, was strongly in favour of importing mustelids, part-financed by the government's subsidy paid against evidence of rates collected by the Board for destruction of rabbits, of circa $£ 2,000$ a year.

The Otara and East Coast Rabbit Association, having failed to persuade the government to turn out a sufficient supply of natural enemies to keep down the rabbits in south Wairarapa, requested official confirmation of the subsidy scheme, and details of whether a voluntary body would qualify and on what conditions. The official reply of 4 October 1889 confirmed the government's promised bonus on stoats and weasels landed in the colony for distribution on pastoral and crown lands, fixed at $£ 1$ per stoat and 10 s per weasel, ${ }^{106}$ payable to anyone. Rabbit boards constituted under the Rabbit Nuisance Act of 1882 could claim a 1:1 subsidy, although not all of them did. In Hawke's Bay the debate about how to organise efficient rabbit extermination was conducted for much of the winter of 1890 in the pages of the local papers. Neither scheme gained universal acceptance, so the board decided against spending public money on any further imports until a majority of the stock-owners had expressed approval. ${ }^{107}$

\section{The ships}

All consignments of stoats and weasels were carried by one or other of the two leading operators of passenger steamships on the New Zealand run. The Shaw Savill \& Albion Company ${ }^{108}$ chartered the Ionic and the Doric, and the New Zealand Shipping Company owned all the other ships named in Table 2. Smaller coastal vessels such as the Rotorua and Penguin, operated by the Union Steam Ship Company, distributed cargo to minor ports not visited by the ocean-going vessels.

104 R. Pinney, Notebook M1: Extracts from Benmore Letter Books, 1877-1887. MS-3178/013, Hocken Collections, University of Otago.

105 Correspondence with Cuff and Graham on proposed contract for supply of stoats and weasels, 1886. R17 620 769, Archives NZ, Wellington.

106 Otara and East Coast Rabbit Association, [Re the subsidy for importing stoats and weasels], 1889. R17 620

873, Archives NZ, Wellington.

107 'Hawke's Bay Rabbit Board', Bush Advocate, 27 July 1890.

108 S. D. Waters, Shaw Savill Line: One hundred years of trading (Christchurch: Whitcomb and Tombs, 1961), 76. 
Only the first trial consignment was carried by a sailing vessel, the Waitangi, on which the animals were housed in cages on deck. The ship took four months (December 1882-March 1883) to reach Port Chalmers, and all but 10 of the animals were lost overboard during a storm. ${ }^{109}$ Fortunately, by 1883, the first generation of steamships could make the voyage in half the time taken by the Waitangi; they were much more spacious and equipped with refrigeration. The later success of the stoat and weasel importation program is undoubtedly linked to its coincidence with the beginning of regular schedules on passenger steamers.

The new imports were of great and immediate interest to newspaper readers in New Zealand, especially the runholders. Shipments were widely observed and commented on in the press and in parliamentary documents. From March 1883 to January 1886, newspapers around the country enthusiastically reported the arrival of seven shipments, landing at least 1,322 stoats and weasels alive, mostly in Otago and Canterbury.

The disadvantage of relying on passenger ships appeared in January 1886 when Shaw Savill \& Albion's report of passenger complaints received after the recent voyage of the Ionic ${ }^{110}$ obliged the government to search around for alternative carriers. The Joint Committee on Rabbit and Sheep Acts put pressure on Bayly, pointing out that the painful losses from rabbits were continuing, and the infested area was increasing in both the North and South Islands; the only solution in sight was to 'without delay take steps to provide for a large and constant supply of stoats and weasels'.111

A solution was offered in June 1886 by the Christchurch stock agents Cuff and Graham, who offered to provide stoats and weasels to the government in 'a large and continuous supply' using the cargo ship Elderslie. ${ }^{112}$ However, Bayly discovered that the Elderslie was not suitable, ${ }^{113}$ so the deal fell through. By May 1887, Bayly's next annual report on the rabbit nuisance still could not list any new imports of stoats and weasels. ${ }^{114}$

109 [Waitangi captain's report], Otago Daily Times, 27 March 1883, 2; Shipboard newspaper, 1883. MS Papers 2264, Alexander Turnbull Library, Wellington.

110 Agent General to Colonial Secretary, 21 January 1886. CO361/12, The National Archives, Kew, London.

111 Anon., 'Report of the Joint Committee on Rabbit and Sheep Acts', AJHR I-05 (1886).

112 Correspondence with Cuff and Graham on proposed contract for supply of stoats and weasels, 1886. R17 620

769, Archives NZ, Wellington.

113 B. Fullerton to B. Bayly [report on suitability of SS Elderslie for carrying stoats and weasels], 1886. R24456085, Archives NZ, Wellington.

114 B. P. Bayly, 'Annual Report on the Rabbit Nuisance' [1886-87], AJHR H-18 (1887). 


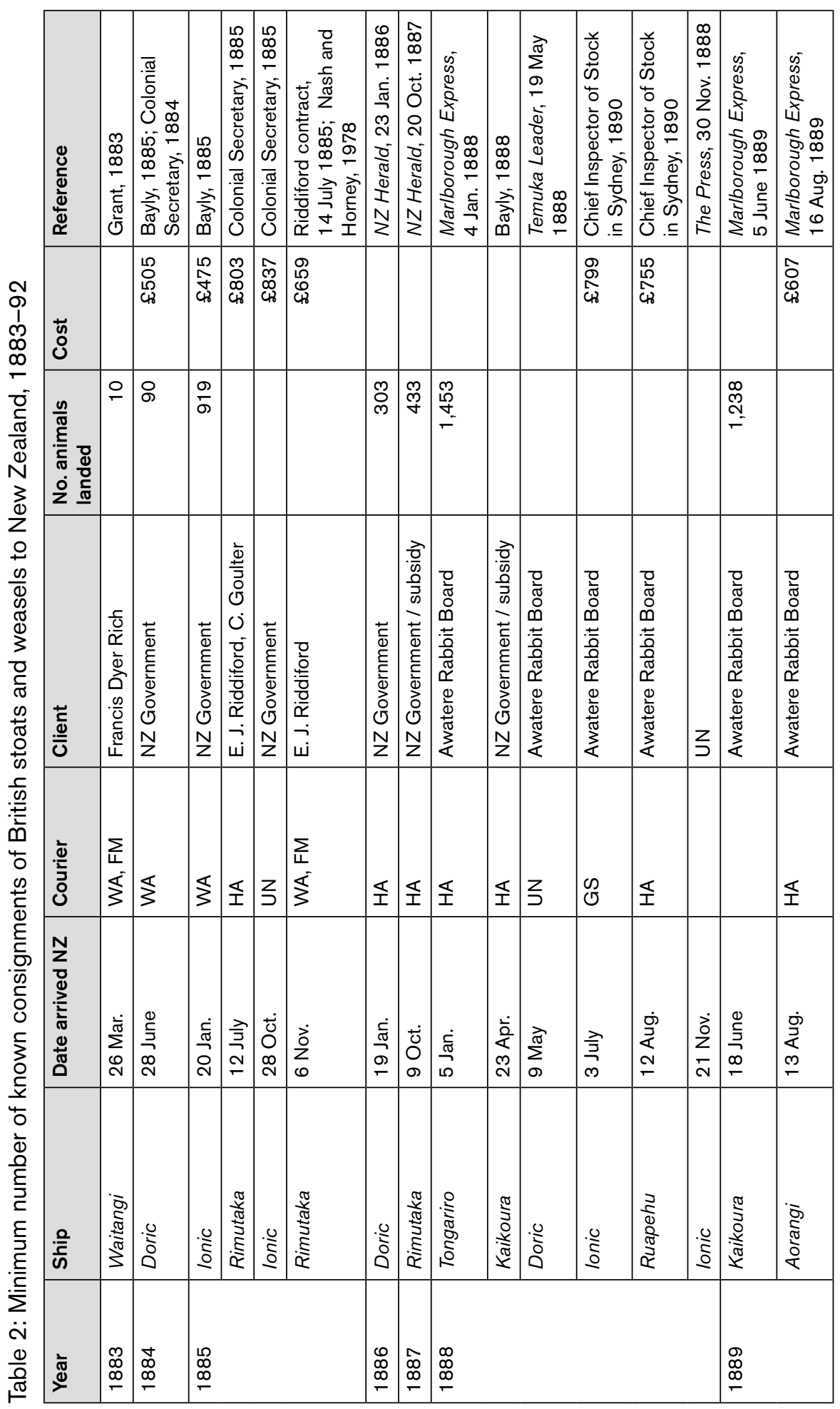




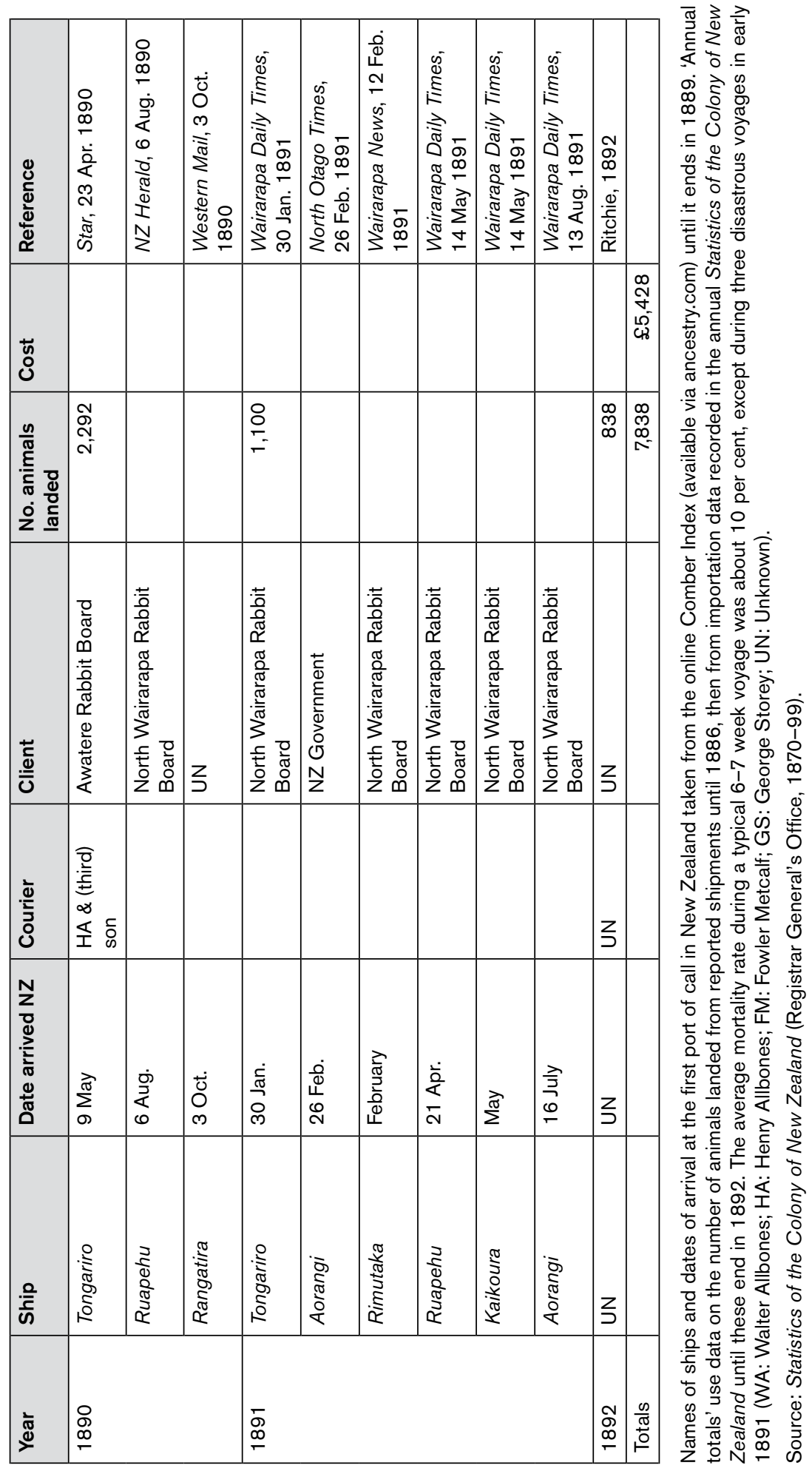


Henry Allbones must have been much vexed by the interruption to his business. In March 1887 he came in person ${ }^{115}$ to negotiate a new agreement with the New Zealand Shipping Company. An interview with Henry in May 1887 mentioned that Walter had brought five shipments so far (all listed in Table 2), 'making 1160 stoats and weasels, and there was another shipment for Mr Rich, of Bushy Park, I think, of which most were drowned'. Asked if he could arrange some more, he said he could. ${ }^{116}$

Henry's foresight and family connections ensured the fastest possible resumption of his business. Back in Brigg, Walter must have been notified of Henry's new shipping arrangements by telegraph, because advertisements immediately appeared in several British newspapers: 'Wanted, by May 29, 150 Weazels and 200 Stoats for New Zealand'. ${ }^{117}$ Henry got them back to New Zealand in the Rimutaka in October 1887 , and signed a new contract with the government, on the usual terms. ${ }^{118}$

\section{The costs}

The earliest record is also for the smallest consignment (Table 1); the larger shipments organised later cost much more. Riddiford had to pay $£ 80316 \mathrm{~s} 8 \mathrm{~d}$ for his first consignment, which arrived in the Rimutaka in July $1885,{ }^{119}$ an eye-watering amount charged to a single individual (NZ\$148,000 in today's money). The Awatere Rabbit Board's first order in October 1887 cost about $£ 2,000,{ }^{120}$ delivered in five shipments (Table 2). Two of them are listed in detail in official correspondence: 295 animals from the Ionic cost on average $£ 214 \mathrm{~s} 2 \mathrm{~d}$ per head, and 312 from the Ruapehu, $£ 214 \mathrm{~s} 2 \mathrm{~d}$ per head. ${ }^{121}$ In February 1889 the Awatere Board placed a second order for $£ 1,200$ worth of stoats and weasels (enough for a 'supply of 600 vermin'), which were delivered in three shipments (270 in the Kaikoura in June 1889, and 227 in the Aorangi in August 1889), each charged for separately. For the third lot in May 1890, 225 brought in the Tongariro at 54s a head, Henry Allbones charged the board $£ 60710$ s, plus a $£ 10$ gratuity and his passage money home. The total known cost incurred by all clients over the 10 years was at least $£ 5,428$, or (allowing for the number of gaps in the data, more likely twice that by the end of 1892) more than $\mathrm{NZ} \$ 1-2$ million in today's money.

115 Passenger records, Card indices, 1885-90. Archives NZ, Wellington.

116 'Stoats and weasels' [Allbones interview], Weekly Press, 20 May 1887.

117 'Stoats and weazels wanted', Stamford Mercury, 6 May 1887.

$118 \mathrm{H}$. Allbones to Minister in Charge of Livestock, Wellington: Acceptance of contract terms, 12 October 1887. R17620769, Archives NZ, Wellington.

119 Colonial Secretary and E. J. Riddiford, Correspondence re accounts for Rimutaka shipment, 1885. Riddiford Family Papers, MS-574-006, Alexander Turnbull Library, Wellington.

120 [Awatere Rabbit Board], Grey River Argus, 5 October 1887.

121 Chief Inspector of Stock in Sydney, Enquiry re success and costs of importing stoats and weasels into New Zealand, 1890. R17621006, Archives NZ, Wellington. 


\section{The shipments}

The survivors of first consignment, accompanied in the Waitangi by Allbones and Metcalf, were safely delivered to Rich at Bushey Park in March 1883 (Table 2). Walter wrote to his fiancée Annie to confirm his safe arrival; ${ }^{122}$ Rich promptly engaged Walter to work on his station to kill rabbits. ${ }^{123}$

Much encouraged, ${ }^{124}$ the colonial secretary agreed to offer 'a good bonus' to anyone who will 'introduce a certain number of these animals in a healthy condition' - a deal that was advertised as 'liberal support' for private importers-but Bayly wanted more systematic action. He urged the colonial government to import their own stocks of stoats and weasels ${ }^{125}$ as well as subsidise private importers.

On 4 December 1883, Thomas Dick, the Colonial Secretary in Wellington, wrote to the agent general in London the key letter that committed the government to take part in what had hitherto been an entirely private game. It states that Walter Allbones was on his way to England in the Tongariro, armed with the first official contract to collect a consignment of weasels and stoats for import to New Zealand. Allbones had been selected for this service because of his special knowledge of the animals, as proven by his work for Rich of Bushy Park; Grant of Castlethorpe, Brigg, Lincolnshire, was cited as a referee. ${ }^{126}$ Walter delivered his first official consignment via the Doric in June 1884. ${ }^{127}$ Bayly confirmed the link to Rich's pioneering effort, ${ }^{128}$ and Walter was immediately commissioned to return home and obtain a further shipment, all expenses paid.

During the 13 months from January 1885 to January 1886 inclusive, five separate shipments of stoats and weasels arrived, totalling 1,222 animals. Three lots were commissioned by the government for turning out on crown lands, mainly in the South Island, and two were private orders for properties in the southern North Island (Table 2).

Shipments stopped after January 1886, while arguments raged about passenger complaints. In May 1887 Henry Allbones made his own arrangements to overcome the disruption to his business, and thereafter his system ran like clockwork to clear the backlog. He dispatched two shipments from England before the end of 1887,

122 W. Allbones to Annie, 2 April 1883. M. Moerbe, private collection, Brigg, Lincolnshire.

123 Samuel Grant to Major Teschemaker, 1883. R24413234, Archives NZ, Wellington.

124 Bayly, 'Annual Report on the Rabbit Nuisance' [1882-83].

125 Bayly, 'Annual Report on the Rabbit Nuisance' [1882-83].

126 Outwards Letterbook-Agent General. Colonial Secretary to Agent General [re Allbones commission], 4 December 1883. R20557923, Archives NZ, Wellington.

127 Outwards Letterbook-Agent General. Letter to Agent General, 14 July 1884. R20557923, Archives NZ, Wellington; 'Stoats and Weasels', The Field, 26 April 1884, 566.

128 B. P. Bayly, 'Annual Report on the Rabbit Nuisance' [1883-84], AJHR H-2 II (1884). 
which arrived in the Rimutaka in October and the Tongariro in January 1888. The government was impressed, and granted him a new contract. ${ }^{129}$ In these two years alone, 1,886 stoats and weasels were landed from seven shipments (Table 2).

The British press marvelled that the New Zealand government had spared no expense in acquiring nearly 2,000 stoats and weasels already, yet the demand continued to exceed supply. The 'shillings paid to buy stock in England turn into guineas [ $£ 1$ s s] when the animals are sold in New Zealand'. ${ }^{130}$

The year 1889 was a bad one for the hitherto indefatigable Chief Rabbit Inspector Bayly. As stoats and weasels spread into native forests and began to kill birds rather than rabbits, ${ }^{131}$ the continuing objections from settlers and others persuaded the government to end all official imports of stoats and weasels (imports of ferrets had been abandoned in 1884). The many supporters of continued imports were ignored. ${ }^{132}$ Bayly was demoted to the office of an ordinary district sheep inspector in Auckland, where rabbits were few and stoats and weasels had not yet reached. ${ }^{133}$ The annual report to the Rabbit Nuisance Committee dated 18 May 1889 was written by an unnamed official. ${ }^{134}$ In June 1890, Bayly was dismissed, ${ }^{135}$ and from then on, his name disappears from the archives.

The independent Joint Committee on Livestock and Rabbits strongly criticised the change in policy connected with the removal of Bayly's influence, in the most uncompromising terms. They regarded the decision as 'a national calamity' which should be immediately reconsidered. ${ }^{136}$ Nothing happened. In 1890 , the Joint Committee on Livestock and Rabbits repeated its 1889 criticism of this shortsighted change in policy. The committee asked why, since the rabbit nuisance was continuing to spread, at an annual loss to the colony 'probably equal to the interest on our national debt', was the government ignoring the need to bring in stoats and weasels 'in large and continuous numbers'?137 Nothing changed: the Rabbit Nuisance Committee's report for 1891 does not mention natural enemies at all. ${ }^{138}$

In 1890, the official import records list a total of 2,292 stoats and weasels arriving, but newspapers mention only three shipments. It seems that by this stage the press in both countries was beginning to lose interest in the matter. But from other

129 H. Allbones to Minister in Charge of Livestock, Wellington: Acceptance of contract terms, 12 October 1887. R17620769, Archives NZ, Wellington.

130 'Politics and Society', Leeds Mercury, 9 November 1887, 4, 5.

131 King, 'Liberation and spread of stoats and weasels', 163-77.

132 E. Clifton, 'Monthly report for Wellington area to Stock Inspector', 1889. R17620841, Archives NZ,

Wellington.

133 Anon., 'Annual Report on the Rabbit Nuisance' [1888-89], AJHR H-13 (1889)

134 Anon., 'Annual Report on the Rabbit Nuisance' [1888-89], AJHR H-13 (1889).

135 'Parliamentary Notes', New Zealand Herald, 21 June 1890.

136 J. B. A. Acland, 'Report of Joint Committee on Live stock and Rabbits', AJHR I-11 (1889).

137 G. Randall Johnson, 'Report of the Joint Committee on Livestock and Rabbits', AJHR I-11 (1890).

138 Anon., 'Report of the Rabbit Nuisance Committee [1880-81]', AJHR I-6 I (1881). 
sources we know that, during the first seven months of 1891, three of six shipments delivered to the North Wairarapa Rabbit Board recorded unusually high mortality of stoats and weasels. Only 42 (11 per cent) of the 374 stoats and weasels loaded on to the Tongariro were still alive by the time the ship arrived in January; only 13 of 93 stoats (13 per cent), plus 2 of 185 ferrets and none of 28 weasels survived to the end of the voyage of the Aorangi on 26 February. The Kaikoura's exceptionally large cargo of 532 animals suffered 'extraordinary mortality' en route, attributed by the receiving inspectors to 'want of cleanliness'. ${ }^{139}$ One can understand the problems of regular cleaning of so many boxes, and of managing enough live pigeons to feed so many animals. Perhaps the experiments proposed more than once in previous years, for cutting costs by feeding frozen meat, proved as unsuccessful as Allbones had predicted.

The long procession of shipments of stoats and weasels to New Zealand remained a matter of continuing interest to newspapers in England. The Pall Mall Gazette commented admiringly in April 1891 on this 'increasing business', which was now 'a very profitable occupation' for the Loan and Mercantile Agency. Actually, by that time the business was no longer increasing, because the Wairarapa Rabbit Board was developing serious doubts, probably shared by others. Ratepayers complained about the great expense of the importations from Britain, especially when half of any loss came out of their pockets. In August the board agreed that it 'should seriously consider the question as to whether it is advisable to import more', since ferrets 'can be bred in the district at about one third less cost than stoats and weasels can be imported'. ${ }^{140}$ From the end of 1891 onwards, the 'Stoats and weasels' import category disappeared from the annual statistical report. Local newspapers continued to report settlers' despair at the spread of stoats and weasels into country without rabbits, ${ }^{141}$ but no new arrivals. International criticism of the mustelid introduction program continued for long after all official imports had stopped in $1889 .{ }^{142}$ On the other hand, thousands of ferrets continued to be locally bred and released well into the 1900s, and not everyone could distinguish the three species. ${ }^{143}$

139 'Rabbit Board', Wairarapa Daily Times, 14 May 1891.

140 'Rabbit Board', Wairarapa Daily Times, 14 May 1891.

141 King, 'Liberation and spread of stoats and weasels', 163-77.

142 [Comment from Australia], Colonist, 20 November 1894.

143 A. H. Clark, The invasion of New Zealand by people, plants and animals: The South Island (New Brunswick, NJ:

Rutgers University Press, 1949). 


\section{Social responses}

The history of stoats in New Zealand can be interpreted as an extended commentary on the development of social interactions between (a) a colonial society still developing its own national identity distinct from its European roots, ${ }^{144}$ and (b) a slowly strengthening indigenous conservation lobby learning (with encouragement from local and European naturalists) to protect native fauna from Darwinian doom. ${ }^{145}$ Both also had to labour against the widespread philosophical assumption in favour of deliberately creating a 'Britain of the South', full of superior European animals, just like Home, only better. ${ }^{146}$

Together, these early attitudes were enough to overrule the long-standing rational objections to the introduction of stoats and weasels, well summarised during Grey's attempt to make them illegal. Fiona Farrell has picked up some of these themes, and converted them into a subtly critical novel designed to make a serious point about parallel modern misjudgements on genetic modification. ${ }^{147}$ Farrell created fictitious characters using the real names of Walter Allbones and Fowler Metcalf, without anticipating that their descendants would see her story as a slur (although an unintentional one) on their families.

Many of the key players in these events (including Robert Campbell, Rich and Teschemaker) were members of the Dunedin Club, established in $1858 .{ }^{148}$ These and other wealthy southern runholders were described as 'men of refinement and education', with extensive commercial interests at stake, as the list of members shows. ${ }^{149}$ The rigid class distinctions of the time helped to ensure that they did not represent the ordinary (mostly unfranchised) settlers, and that they could ignore any outside advice irrelevant to their concerns. As the historian Paul Star put it: 'The eventual introduction of mustelids represented the victory of income over the environment, of landholders' desperation over scientific foreboding. ${ }^{150}$

The system of provincial government of the 1860s put political power into the hands of these 'southern gentry', ${ }^{151}$ because they were in the best position to exert a disproportionate influence on nineteenth-century business and government, even though they did not represent the ordinary landholders. ${ }^{152}$ They all faced the same

144 Wells, 'An enemy of the rabbit', 269-96; Star, 'Nature's Trump Card', 3-9.

145 R. Galbreath, Walter Buller: The reluctant conservationist (Wellington: GP Books, 1989).

146 C. Hursthouse, New Zealand, or Zealandia, the Britain of the South (London: Edward Stanford, 1857).

147 F. Farrell, Mr Allbones' Ferrets (Auckland: Random House, 2007).

148 Anon., 'The Squatters' Club', Friends of Hocken Bulletin 58 (2008); J. H. Beattie, The Southern Runs (Gore: Gore Historical Society, 1979).

149 Anon., 'The Squatters' Club'; Beattie, The Southern Runs.

150 Star, 'Nature's Trump Card', 3-9.

151 S. Eldred-Grigg, A Southern Gentry; New Zealanders who inherited the earth (Wellington: A. H. and A. W. Reed, 1980), 57.

152 Star, 'Nature's Trump Card', 3-9. 
disastrous economic conditions brought on by the rabbits, and all of them lost huge amounts of money. ${ }^{153}$ Campbell's family connections gave him deeper pockets than most, but in 1881 he gave up on at least seven of his previously profitable runs. Cuthbert Cowan was not a member of the club, but no doubt interacted with them in Wellington during his years as a member of the House of Representatives in $1884-90 . .^{154}$

A clear illustration of the conflicts of interests and social counter-currents complicating the introductions program is provided by Charles Teschemaker. In 1884 he spent two months in Devon, attempting to out-compete Allbones by arranging cut-rate shipments. Teschemaker's naïve approach to the specialised business of handling highly strung wild animals was made worse by the social divides among his informants. At the top end of the social scale, he found it difficult to get information from the landowners because they wanted stoats destroyed, 'not kept as valuable'. At the other end, since the trappers discovered money could be made from live stoats and weasels, they were developing ways to maximise the harvest. They told him that 'it is impossible to procure the animals now' (September 1884), which was probably quite untrue, because September is normally a good time for trapping the annual cohort of newly independent young. ${ }^{155}$ Instead, they 'passed word around the county for 50 miles $[80 \mathrm{~km}$ ] that no stoats should be killed but all saved to be trapped after they have had young ${ }^{156}$ [i.e., in the spring of 1885].

By 1887 , the social fabric of the South Island was being severely strained by another controversy, the immigration of Chinese goldminers. ${ }^{157}$ One newspaper printed a cartoon entitled 'Imported Pests', unashamedly drawing a connection between the two (Figure 4).

By the end of 1886, even some English landowners were beginning to wonder what effect the exports were having on 'the balance of nature' on their own estates. The numbers of animals removed for export were probably only substituting for the numbers normally killed by gamekeepers, but people began to ask whether local increases in rats and field voles could be due to the removal of their natural enemies. ${ }^{158}$ The Colonist reported that landowners of six British counties agreed in 1886 to prohibit the export of 'stoats and weasles' to New Zealand. Ironically, the same argument was cited in support of the policy of importing mustelids into New Zealand: 'The remonstrances of the Lincolnshire farmers against the continual export of these animals should be a convincing proof of their usefulness'. ${ }^{159}$

153 Sinclair, 'High Street Quaking'.

154 Jane Thomson, ed., Southern People: A dictionary of Otago Southland biography (Dunedin: Longacre, 1998).

155 King and Powell, The Natural History of Weasels and Stoats.

156 C. de V. Teschemaker, B. P. Bayly and Colonial Secretary, Correspondence concerning Teschemaker, 1884.

R24413234, Archives NZ, Wellington.

157 J. H. M. Salmon, A history of goldmining in New Zealand (Wellington: Government Printer, 1963).

158 'The Weasel, Mustela vulgaris', Zoologist 3rd ser. 18 (1894): 446.

159 'Rabbit extermination', Hawke's Bay Herald, 5 June 1890. 


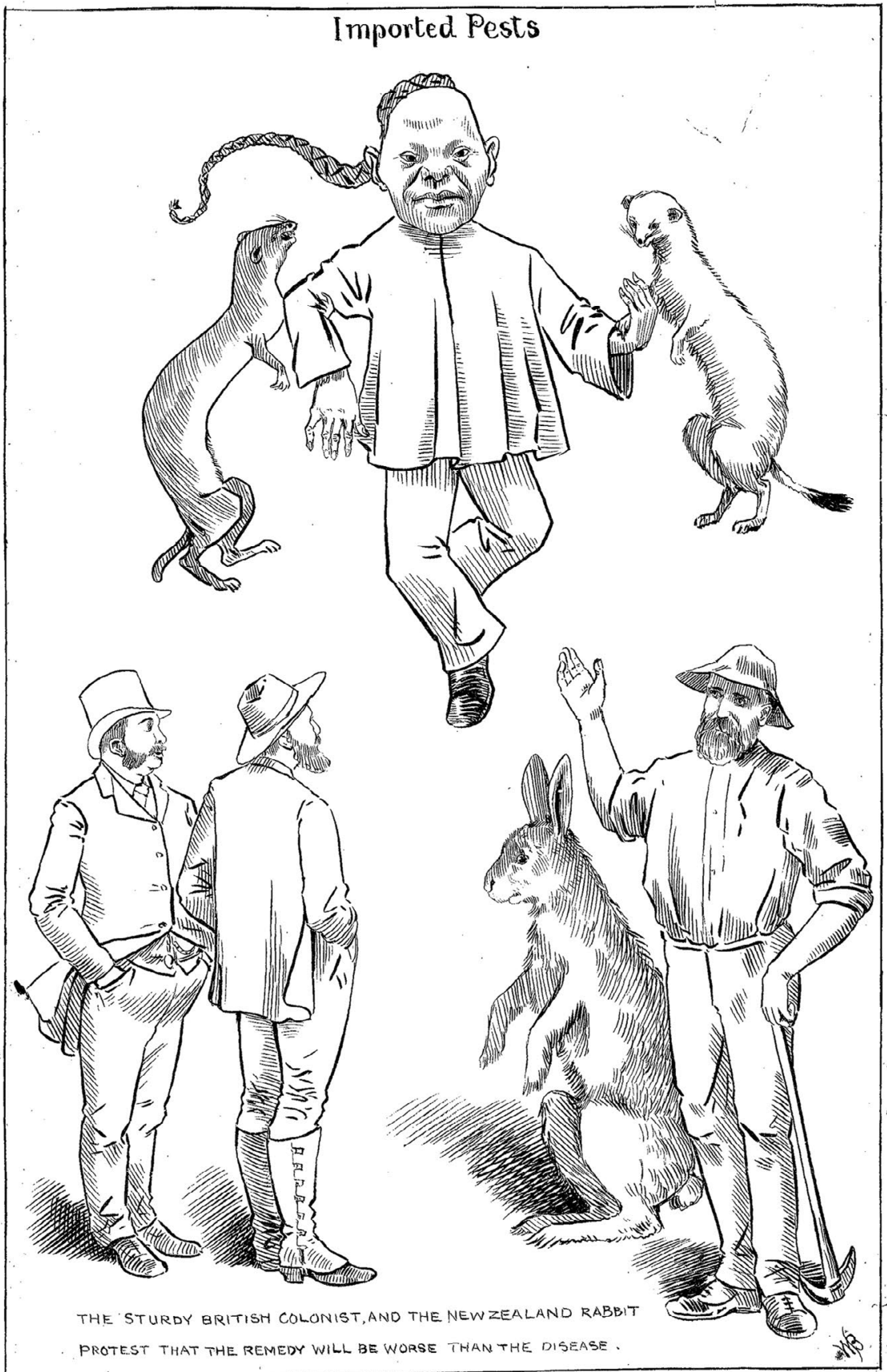

Figure 4: Cartoon illustrating the strength of local feeling against two forms of imported pests

The caption reads: 'The sturdy British colonialist, and the New Zealand rabbit, protest that the remedy will be worse than the disease.'

Source: New Zealand Observer and Free Lance, 16 April 1887. 


\section{Did the strategy work?}

The effect of a predator on its prey is never entirely predictable, because it is a matter of numbers (added to and removed from the prey population) and relative rates of fertility and mortality on both sides, which are both highly variable with habitat and season, among many other parameters. In the naïve view of this apparently simple process, the subtraction rate imposed by predators is assumed always to beat the multiplication rate of prey.

One of the few contemporary observers to recognise the real and dynamic relationship, Richard Henry, poured scorn on claims that stoats and weasels were or could ever have been successful in controlling rabbits. He pointed out that 'we brought the stoat from the same place as the rabbit, where they lived and throved [sic] together for thousands of years'. He scoffed at Bayly's conclusion that the weasels released near Wanaka in 1884 were responsible for an apparent reduction in rabbit numbers; in reality, 'Bunny undoubtedly disappears from a locality where there is anything objectionable, and he may well be proud of so easily befooling us'. ${ }^{160}$

No, Henry concluded, the real natural enemy of any animal is that which removes its food, which in turn, as twentieth-century research subsequently confirmed, depends on habitat conditions. This logic helps to explain why the rabbit can be a devastating natural enemy of the sheep, but the stoat is not the primary natural enemy of the rabbit, unless rabbits are already under stress from some other cause such as drought or a poisoning operation. On the contrary, to the extent that stoats can reduce the numbers of rabbits at all, they can only help to improve the food resources of the remaining rabbits, whereas sufficient numbers of rabbits could and did destroy the food resources of sheep over vast areas of pastoral land in the nineteenth century. At that time, stoats and weasels were usually liberated where rabbits were already hugely abundant, but in groups too small to achieve a rate of increase matching that of rabbits. Henry was a hundred years ahead of his time in anticipating the conclusions of contemporary community ecology ${ }^{161}$ by confirming that predators generally follow, rather than control, the numbers of fast-breeding prey such as rabbits or rodents.

160 Richard Henry, The New Zealand rabbit and its prey (Christchurch: Lyttelton Times, 1887).

161 R. P. Pech et al., 'Limits to predator regulation of rabbits in Australia: evidence from predator-removal experiments', Oecologia 89 (1992): 102-12; C. Jones et al., 'Functional responses of an invasive top predator Mustela erminea to invasive meso-predators Rattus rattus and Mus musculus, in New Zealand forests', Wildlife Research 38, no. 2 (2011): 131-40. 
In July 1900 the New Zealand government received an official enquiry from Sydney as to the advantage or otherwise of introducing weasels for the purpose of keeping down the rabbit pest, and, if advisable, how to obtain them. J. D. Ritchie's formal reply ${ }^{162}$ provides an unprecedented post-hoc assessment of official thinking, formulated only a few years after the New Zealand imports had ceased.

Ritchie agreed with the usual assumption that stoats and weasels had helped to check rabbit numbers in the high country, but pointed out that rabbits in those same areas had been poisoned first, so the predators could not take all the credit, and new introductions were not advisable. He added that stoats and weasels had spread throughout the colony including to places with no rabbits, but official offers to remove captured individuals from uninfested to infested districts had not been taken up. Unsurprisingly, Australia decided against importing stoats and weasels; foxes were already bad enough.

Rabbits are a pest in many countries, but Bayly's solution was never tried on such a scale anywhere else in the world. Nothing could have prevented three species of rats from running ashore from canoes and ships, and each in turn has done untold devastating damage to native fauna, but the list of species at risk ${ }^{163}$ might now be shorter if stoats and ferrets had never been brought to New Zealand.

\section{Conclusions}

The circumstances and world views of the colonists in New Zealand who found themselves at serious financial risk from invasive rabbits were very different from those of present-day farmers working in the same areas. Original contemporary documents provide the best way to appreciate these differences, because they show why official and private decisions made then, that we now find amazing, seemed fully justifiable at the time. Ideas in colonial New Zealand on how to control rabbits were based on the simple assumption that every rabbit killed by a 'natural enemy' would be one rabbit fewer in the population. Hence, stoats and weasels were confidently assumed to be actually capable of preventing the spread of rabbits from their earliest release areas, and no other factors controlling rabbit populations were considered. Besides, in contrast to the declining and inferior native predators, they were British. ${ }^{164}$

162 [Complaints about natural enemies], 1896-98. R1762009, Archives NZ, Wellington.

163 J. Innes et al., 'Predation and other factors currently limiting New Zealand forest birds', New Zealand Journal of Ecology 34, no. 1 (2010): 86-114.

164 Star, 'Nature's Trump Card', 3-9. 
Hard experience showed that the fertility rates of adult rabbits and the survival rate of the juveniles can be very high, given good habitat and climatic conditions, ${ }^{165}$ and rabbit populations normally have a high natural mortality rate, which additional losses can seldom exceed. Those conditions were met in wide areas of the thick tussock grasslands of Southland and Otago in the 1860s, which explains why, once the initial invasion of rabbits moved into its exponential phase in the 1870 s, it could not have been predicted or stopped by any tools available to ninteenthcentury landholders. ${ }^{166}$ Unfortunately, they did not know that the same applied to 'the natural enemy'.

Just as the American mink was freely admitted to Britain to establish fur farms, ${ }^{167}$ so the introduction of mustelids to New Zealand was actively encouraged by officialdom-so long as these animals were seen as having an economic value. Mink farms were a reliable source of luxury fur, while stoats and weasels were seen both as self-perpetuating allies in the battle against the rabbit pest and a source of rural employment. In both cases, and in other countries transformed by introduced species around the world, ${ }^{168}$ repeated warnings of the risk of introduced animals becoming an irreversible serious threat to their new environments were simply overruled by the profit motive.

With hindsight, contemporary historians and biologists alike might ask: were the Victorians alone in their confident assertion of human power over nature, or have their descendants learned something? The surviving documentation describing attempts to control rabbits in the colonial New Zealand of the 1880s is a sobering record of the urgency and optimism with which the responsible authorities chose to deploy mustelids, a potent new tool, against all opposition from a vocal but powerless minority who valued the 'inferior' native biota more than sheep. ${ }^{169}$

Since then, perceptions have changed; native species are national treasures worthy of expensive protection measures, and environmental management authorities faced with pest management dilemmas are more aware than they were before that ecosystem-level processes cannot necessarily be predicted from observations of individuals, and that in nature, managers cannot change only one thing. We pick our battles more carefully now, and have a world-beating record of success in wildlife

165 G. Norbury and B. Reddiex, 'European rabbit', in Handbook of New Zealand mammals, 2nd ed., ed. C. M. King (Melbourne: Oxford University Press, 2005), 131-50; Thompson and King, The European Rabbit.

166 Peden, Making Sheep Country.

167 J. Sheail, 'The Mink Menace: The Politics of Vertebrate Pest Control', Rural History 15 (2004): 207-22.

168 Crosby, Ecological Imperialism.

169 One runholder told parliament that he 'was very fond of birds; but if it came to a question whether he would have birds or sheep, he would certainly vote in favour of the sheep'. Capt. Fraser, New Zealand Parliamentary Debates (1876), 613. 
conservation on offshore islands. ${ }^{170}$ Our aspirations are more ambitious than ever, ${ }^{171}$ but they are informed by the failures of the past-including those most bitter of lessons, taught by stoats, weasels and ferrets.

\section{Acknowledgements}

This project would have been impossible without the help of many people, especially Ken Ayers, who did much of the early archival searching both in New Zealand and in the UK.

Librarians: Judith Holloway (Hocken Collections, Dunedin), Cheryl Ward (Waikato University), Emma Knowles (Toitū Otago Settlers Museum, Dunedin), Rachael Gardner and Marion Lowman (Bodleian Library, Oxford) and duty staff at the libraries of the Zoological Society of London and Cambridge University.

Archivists: Chris Meech (Waitaki District Archive), Katherine C'Ailceta, Donal Raethel (Archives NZ, Wellington), Kas McEntyre (Alexandra), Rebecca Smith and Sonya Johnson (Invercargill), Anne Maguire (Arrowtown), Fiona Passi (Auckland), many staff at the National Archives (Kew), National Maritime Museum (Greenwich), Berkshire Record Office and Museum of English Rural Life (Reading).

Information: David Allbones, Ken Ayers, Dawn Coburn, John Dyer, Fiona Farrell, Nigel Fisher, Ian Green, Peter Holland, Frank Leckie, Rachel Letofsky, Fay McDonald, Tessa Mills, Maxine Moerbe, Pat Morris, Mark and Claire Strawson and Evan Tosh.

Hospitality: Daphne and Bill Lee (Dunedin), Anne Sudell, Jeff and Kate Booth (Wellington), Joan Moerbe née Allbones and Maxine Moerbe (Brigg), Wolfson College, Cambridge, and Lauren Harrington (Oxford).

Funding: University of Waikato RTCF Grant 2016/104615. The funder had no role in study design, data collection and analysis, decision to publish, or preparation of the manuscript.

Helpful comments on early drafts: Ken Ayers, James Beattie, Tom Brooking, Ian Green, Peter Holland, Daphne Lee and Andrew Veale.

170 J. C. Russell et al., 'Importance of lethal control of invasive predators for island conservation', Conservation Biology 30 (2016): 670-2.

171 Russell et al., 'Predator-Free New Zealand', 520-5. 
This text is taken from International Review of Environmental History, Volume 3, Issue 2, 2017, edited by James Beattie, published 2017 by ANU Press, The Australian National University, Canberra, Australia.

dx.doi.org/10.22459/IREH.03.02.2017.04 